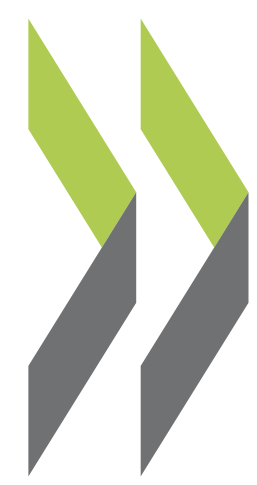

OECD Economics Department Working Papers No. 336

\title{
Strengthening \\ the Management of Public Spending in Hungary
}

\author{
Jaromir Cekota, \\ Rauf Gönenç, \\ Kwang-Yeol Yoo
}


Organisation de Coopération et de Développement Economiques

Organisation for Economic Co-operation and Development

30-Jul-2002

ECONOMICS DEPARTMENT

English text only

STRENGTHENING THE MANAGEMENT OF PUBLIC SPENDING IN HUNGARY

ECONOMICS DEPARTMENT WORKING PAPERS NO.336

by

Jaromir Cekota, Rauf Gönenç and Kwang-Yeol Yoo

All Economics Department Working Papers are now available through OECD's Internet Web site at http:/www.oecd.org.eco 


\section{ABSTRACT/RÉSUMÉ \\ STRENGTHENING THE MANAGEMENT OF PUBLIC SPENDING IN HUNGARY}

This paper analyses the Hungarian public expenditure system and develops policy-oriented recommendations for its improvement. Despite substantial progress achieved in the management of public finances over the 1990s, the level of public expenditure and taxation relative to national income has been comparatively high while the budget process has continued to be driven by short-term considerations and remains input- rather than output-oriented. The government's economic pre-accession programme submitted to the European Commission for the time period 2002-04 needs to be complemented by a thorough public expenditure reform in order to achieve its ambitious targets, implying significant fiscal tightening. This reform entails the development of a medium-term, output-oriented expenditure framework characterised by transparent and comprehensive budget procedures for all fiscal activities of the general government. Effective spending in areas critical for future growth performance -- including physical infrastructure and education -- requires reforms in the delivery, funding and planning of public services, notably at the local government level. Fuller transparency of costs and benefits, wider utilisation of comparative benchmarks in monitoring service efficiency and allocating public resources, and wider recourse to competitive and private sector provision of services are desirable reform avenues.

JEL classification: HO, H1, H4, H5, H6, H7

Keywords: Public expenditure, general government, extra-budgetary funds, contingent liability, fiscal discipline, budgetary transparency, multi-year budgeting, programme evaluation

$* * * * *$

\section{AMÉLIORER LA GESTION DES DÉPENSES PUBLIQUES EN HONGRIE}

Cette étude analyse le système des dépenses publiques de la Hongrie et développe des recommendations de politique pour son amélioration. Malgré les progrès réalisés dans la gestion des finances publiques dans les années 1990, le niveau des dépenses publiques et des impots par rapport au revenu national reste relativement élevé, alors que le processus budgétaire est détérminé par des considérations de court terme et se concentre sur des financements d'inputs plutot que de résultats. Le programme économique de pré-accession soumis à la Commission Européenne pour la période 2001-2004 devrait etre complété par une réforme profonde des dépenses publiques pour atteindre ses objectifs ambitieux - qui nécessitent d'importantes économies budgétaires. Cette réforme devrait se baser sur un cadre de dépenses à moyen terme orienté sur les résultats, utilisant des procédures transparentes et exhaustives couvrant l'ensemble des activités des administrations publiques. Des dépenses efficaces dans les domaines importants pour la croissance future -- y compris dans les infrastructures et l'éducation -- nécessitent des réformes dans l'offre, le financement et la planification des services publiques, notamment au niveau des administrations locales. Une meilleure transparence des couts et des bénéfices, une plus large utilisation des "benchmarks" comparatifs dans la surveillance de l'efficacité des services et dans l'allocation des ressources, et un plus grand recours à l'offre concurrentiel et privé de services sont des orientations souhaitables de réformes.

Classification JEL : HO, H1, H4, H5, H6, $\mathrm{H7}$

Mots-clés: Dépenses publiques, administrations publiques, fonds extra-budgétaires, engagements contingeants, discipline budgétaire, budgets pluri-annuels, évaluation des programmes

\section{Copyright OECD 2002}

Applications for permissions to reproduce or translate all, or part of, this document should be made to Head of Publications Service, OECD, 2 rue André Pascal, 75775 PARIS CEDEX 16, France. 
TABLE OF CONTENTS

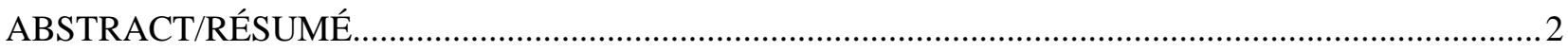

STRENGTHENING THE MANAGEMENT OF PUBLIC SPENDING IN HUNGARY ............................. 4

Hungary remains a relatively high tax and high spending country .................................................... 6

Budget procedures need to be strengthened further ............................................................................

The challenges of reallocating resources in a medium-term perspective: the case of infrastructures .......28

Service supply structures can be considerably improved: the case of education .....................................32

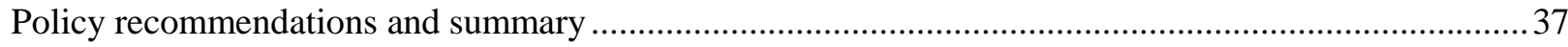

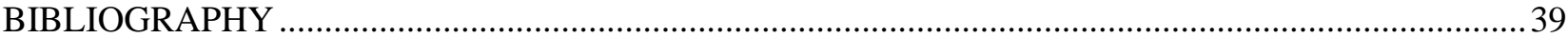

ANNEX I. OECD ADJUSTMENTS TO THE GFS ACCOUNTS IN HUNGARY ....................................44

Boxes

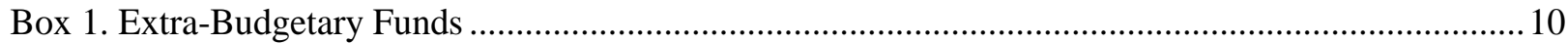

Box 2. The measurement of fiscal stance by cash and accrual-based accounts ...................................... 12

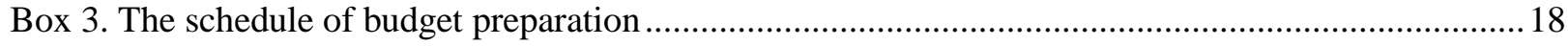

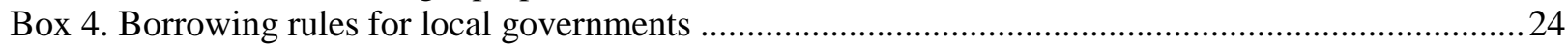

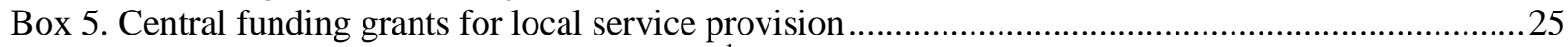

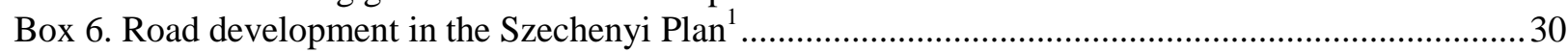

Box 7. Strengthening the management of public spending .................................................................. 37

Tables

1. Growth and risks of loan guarantees

2. Expenditures of selected state-owned companies

3. Differences between cash and accrual-based accounts

4. Tax expenditures

5. State aids

6. The growing role of local taxes

7. Service responsibilities of local governments

8. Teaching and non-teaching staff in the education sector

\section{Figures}

1. Government spending

2. General government outlays by economic category

3. Main components of primary general government outlays

4. Government employment and wages

5. Macroeconomic assumptions of budget forecasts

6. Education spending per student is in line with national wealth but uses more public resources than elsewhere 


\title{
STRENGTHENING THE MANAGEMENT OF PUBLIC SPENDING IN HUNGARY
}

by

\author{
Jaromir Cekota, Rauf Gönenç, and Kwang-Yeol Yoo ${ }^{1}$
}

1. In spite of persisting efforts to decrease total public spending and taxation since the beginning of transition, Hungary remains a relatively high spending and high taxation country (Figure 1). In order to stimulate private savings, investment and growth, policymakers intend to reduce the share of taxes and spending in GDP, as outlined in the medium-term economic programme submitted to the European Commission in 2001. This implies a significant fiscal tightening, which could be accommodated by public expenditure reform. International experience shows that it is possible to simultaneously reduce aggregate taxes and public spending, and still improve the allocation of public resources to equity-enhancing and growth-friendly uses. Reforming budgetary structures, procedures and institutions is key in this respect. This study reviews the Hungarian public expenditure system with a view to identify ways of decreasing the aggregate cost of realising policy objectives and improving the allocative and technical efficiency of government expenditures. It examines the structure of spending in international comparison, the spendingcontaining and spending-inducing features of current budget procedures, the possibilities for redeploying resources to growth-friendly areas in a medium-term framework, and the room for improving the efficiency of existing programmes by reforming service supply structures. Policy recommendations are summarised in a concluding section.

1. An earlier version of this paper served as an input into the 2002 OECD Economic Survey of Hungary, which was published in June 2002 under the authority of the Economic and Development Review Committee of the OECD. Rauf Gönenç is the head of Czech Republic/Hungary desk while Jaromir Cekota and Kwang-Yeol Yoo are economists on the Czech Republic/Hungary desk and on the fiscal team of the General Economic Assessment Division in the Economics Department, respectively. Special thanks are due to Andreas Wörgötter who supervised this project. The authors are indebted to Val Koromzay, Mike Feiner, Andrew Dean, Jorgen Elmeskov, Patrick Lenain, Andrew Burns and Judit Kreko for thorough comments on earlier drafts. Thanks also to Margaret Morgan and Chantal Nicq for technical support, and to Diane Scott for technical assistance. 
Figure 1. Government spending

\section{A. General government expenditures and receipts}

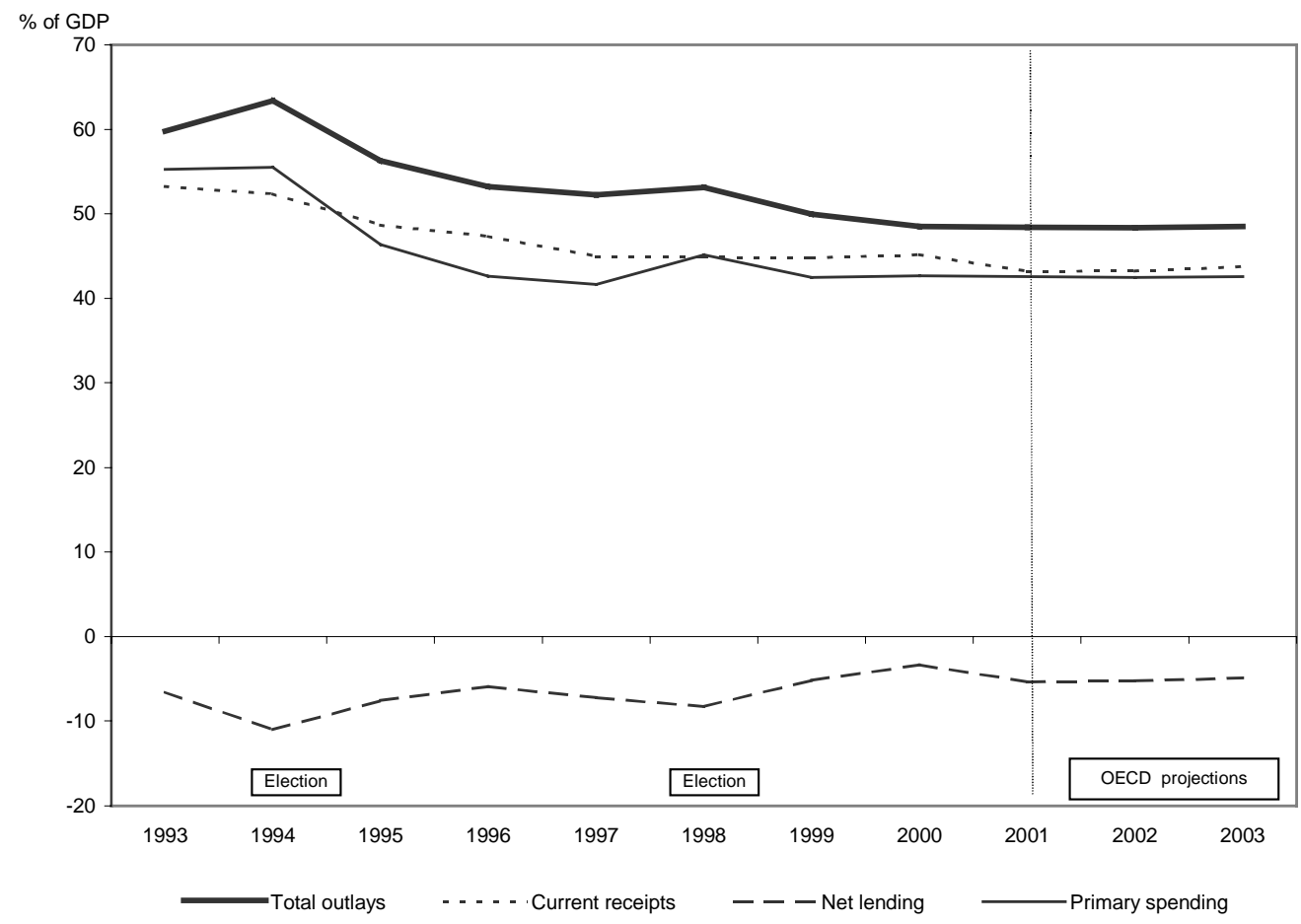

\section{B. Government size in $\mathbf{2 0 0 0 ^ { 1 }}$}

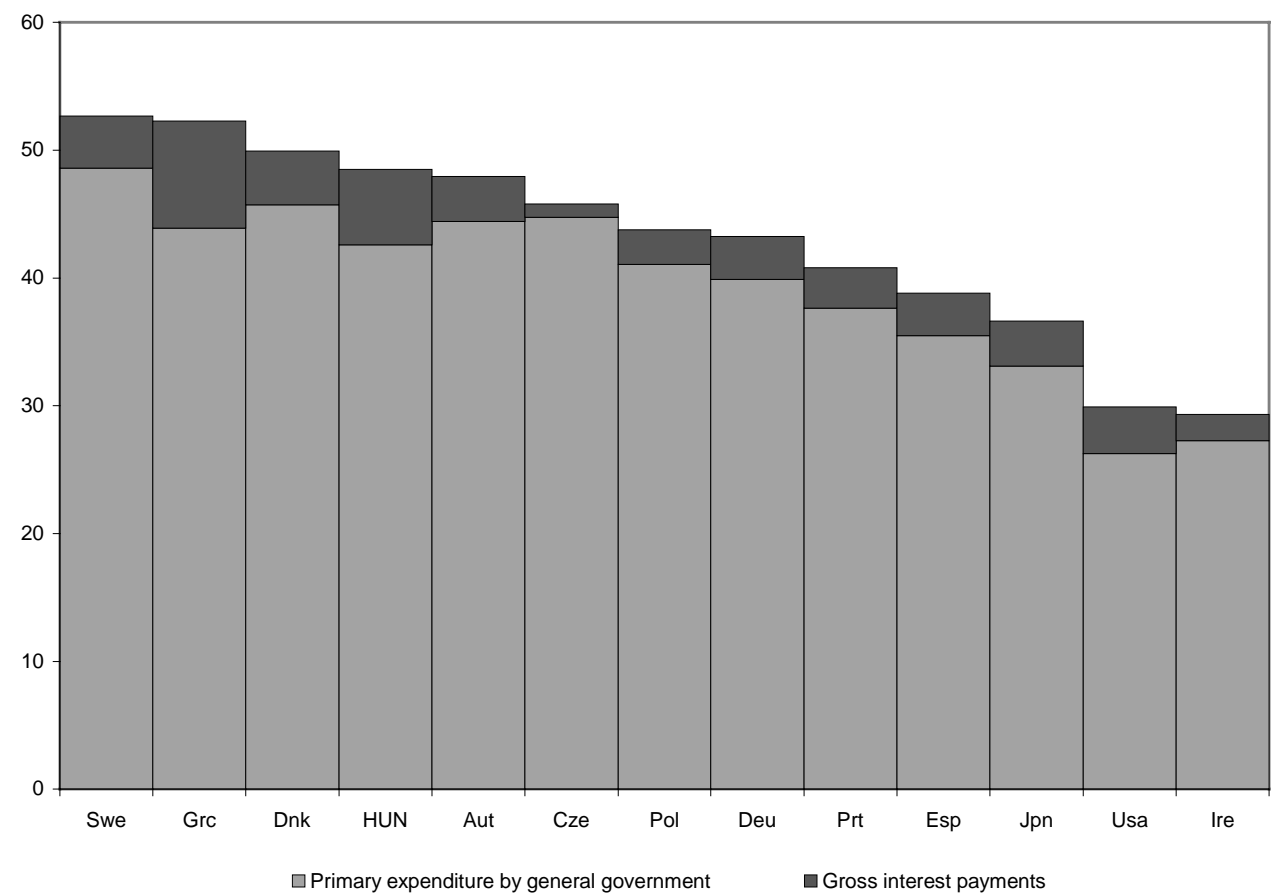

1. Share of total government expenditure in GDP. For Japan, outlays include capital transfers to the Deposit Insurance Company. For the United States, data include outlays net of operating surpluses of public enterprises.

Source: OECD, revised GFS (Government Financial Statistics) accounts; Central Statistical Office. 


\section{Hungary remains a relatively high tax and high spending country}

2. Public expenditures as a share of GDP have grown in the first half of 1990s because of the decline of output and in response to the spending pressures of early transition. However, following an emergency stabilisation package in the mid-1990s, the ratio has declined sharply, decreasing from 63.4 per cent in 1994 to 48.3 per cent in 2000. This rationalisation appears to have ended in 2000, the ratio increasing again to 49.1 per cent in 2001 and to an expected 49.2 in 2002 according to OECD projections. At the same time, signs of fiscal loosening emerge ${ }^{2}$. Hungary appears today as a relatively high tax and high spending country, particularly among economies with a similar level of GDP per capita. The oftenmentioned burden of the public debt is not the only explaining factor of this weight of public spending in GDP, as confirmed by international comparisons of total and primary expenditures (Figure 1). ${ }^{3}$

3. In terms of the broad picture of fiscal spending, total government outlays amounted to 48.3 per cent of GDP in 2000 and were composed of welfare transfers and subsidies (19.4 per cent of GDP), direct government consumption (19.4 per cent), investment in public infrastructure (4 per cent) and the service cost of public debt (5.9 per cent). Functionally and in international comparison, spending items commanding a large portion of expenditures are general public services (7.3 per cent), subsidies to production and consumption ${ }^{4}$ (5.4 per cent of GDP), while social spending in education, health and pensions, without reaching proportions attained in the top spending countries, represent also a significant share of expenditures (22.1 per cent of GDP in aggregate). The composition of expenditures resembles that of high-tax and high-spending Western European countries, hinting at additional spending pressures which may result from the increasing demand for public services with a high income elasticity ${ }^{5}$ (Figures 2 and 3 ).

4. The general government has a particularly large share in total employment. ${ }^{6}$ The public sector remained labour intensive through transition as a result of the combined impacts of job protection, labour market strains which were met by public sector job creation, and limits on productivity-enhancing investments, notably IT applications. These factors have been particularly acute in local governments, which are the largest public sector employers (see below). The 1995 emergency package was aimed at job cuts but ended up with drastic real wage reductions rather than widespread employment adjustments (Figure 4). The challenge now is to achieve high quality public service supply with adequately skilled and paid employees. This will require to downsize employment.

2. The Secretariat estimate of a SNA-compatible government deficit shifted from 3 per cent of GDP in 2000 to 5.2 per cent in 2001 and is projected to reach 5.5 per cent in 2002 .

3. Current primary expenditure rather than total primary expenditure is used for this comparison, as public sector capital building is included to different degrees in the general government accounts of various countries - according to the organisation of public utilities.

4. The bulk of price subsidies go to railway and long-distance bus services and to pharmaceutical price topups (consumers pay lower prices than those received by pharmaceutical companies). It should be mentioned that similar transfers may take less transparent forms in other countries, including through cross-subsidies within public companies and insurance funds, and are not always reflected in general government accounts.

5. Notably in the health, education and pension areas.

6. At 20.3 per cent of total employment without public enterprises and 25.1 per cent by including them. According to available data, the share of general government employment in total employment is about 1215 per cent in most countries, employment in public enterprises adding an average 2-3 percentage points to this proportion (except in the Czech Republic where the additional public enterprise employment amount to 7 per cent of total employment). 
ECO/WKP(2002)22

Figure 2. General government outlays by economic category

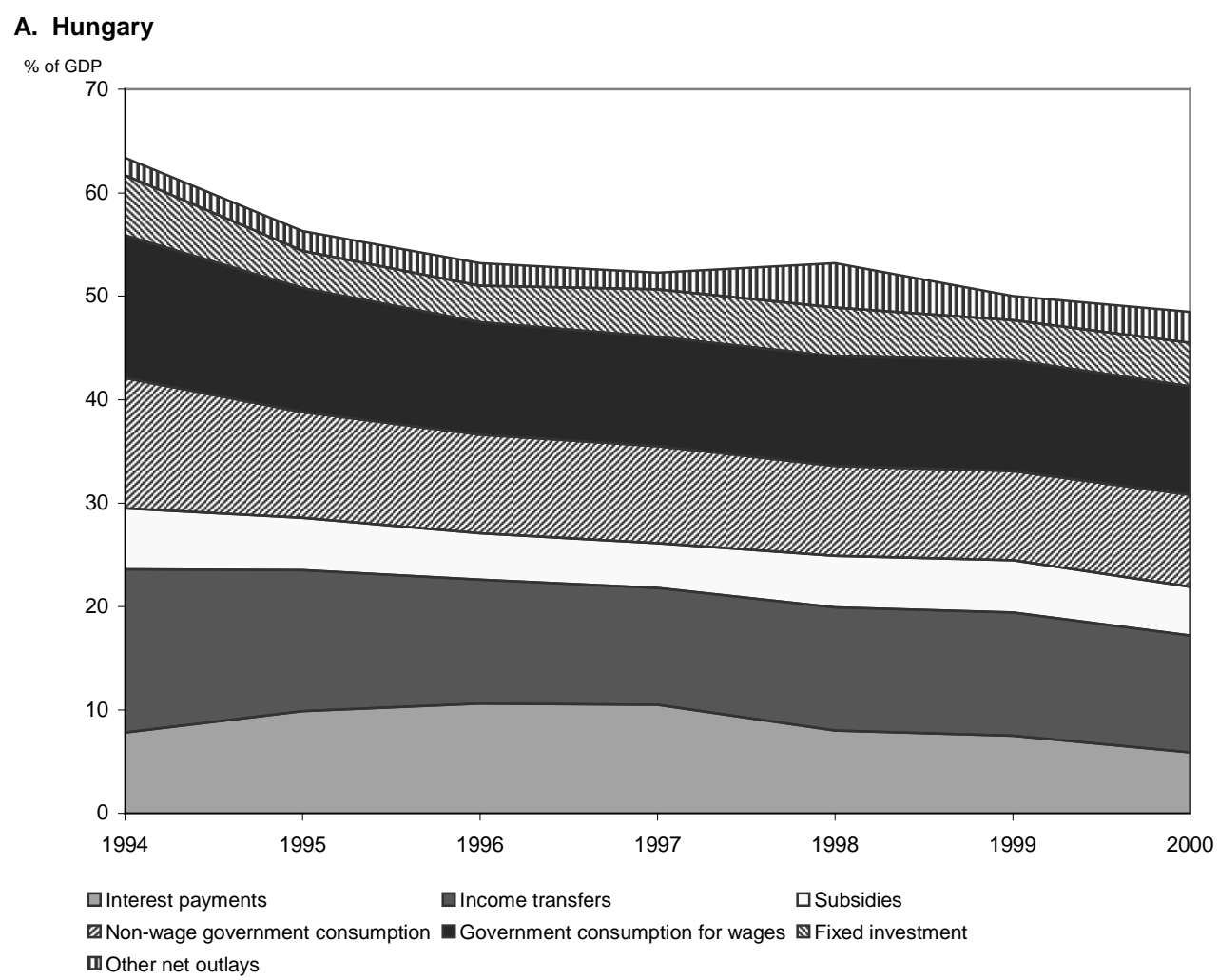

B. International comparison, 2000 $\%$ of GDP

\begin{tabular}{|c|c|c|c|c|c|c|c|c|}
\hline & $\begin{array}{l}\text { Income } \\
\text { transfers }\end{array}$ & Subsidies & $\begin{array}{c}\text { Interest } \\
\text { payments }\end{array}$ & Consum & $\begin{array}{l}\text { on } \\
\text { of which } \\
\text { wages }\end{array}$ & $\begin{array}{l}\text { Gross fixed } \\
\text { Investment }\end{array}$ & $\begin{array}{l}\text { Other net } \\
\text { transfers }\end{array}$ & $\begin{array}{r}\text { Total } \\
\text { outlays }\end{array}$ \\
\hline Austria & 18.7 & 2.6 & 3.5 & 19.4 & 11.3 & 1.7 & 1.8 & 47.7 \\
\hline Czech Republic & 13.6 & 3.0 & 1.0 & 20.4 & 7.6 & 3.5 & 4.8 & 46.3 \\
\hline Denmark & 16.8 & 2.1 & 4.1 & 24.7 & 16.6 & 1.8 & 0.3 & 49.8 \\
\hline France & 18.0 & 1.3 & 3.3 & 23.3 & 13.5 & 3.0 & 2.2 & 51.0 \\
\hline Germany & 18.8 & 1.7 & 3.4 & 19.0 & 8.1 & 1.9 & -1.4 & 43.3 \\
\hline Greece & 16.3 & 0.2 & 8.4 & 15.6 & 11.8 & 4.1 & 7.9 & 52.5 \\
\hline Hungary & 11.3 & 4.7 & 5.9 & 19.4 & 10.5 & 4.0 & 3.3 & 48.5 \\
\hline Ireland & 8.2 & 0.7 & 2.1 & 13.4 & 7.9 & 3.8 & 1.2 & 29.3 \\
\hline Italy & 16.7 & 1.2 & 6.5 & 18.0 & 10.5 & 2.4 & -0.3 & 44.4 \\
\hline Japan & 10.1 & 0.8 & 3.5 & 16.6 & 6.8 & 5.1 & 0.5 & 36.6 \\
\hline Korea & 4.0 & 0.3 & 0.8 & 10.0 & 7.2 & 5.7 & 2.5 & 23.1 \\
\hline Poland & 18.9 & 1.1 & 4.7 & 15.8 & 10.9 & 3.4 & -0.1 & 43.8 \\
\hline Portugal & 14.0 & 0.9 & 3.1 & 20.5 & 14.8 & 4.2 & -2.0 & 40.7 \\
\hline Spain & 12.3 & 1.1 & 3.3 & 17.4 & 10.3 & 3.3 & 1.4 & 38.8 \\
\hline Sweden & 18.4 & 1.9 & 4.3 & 26.1 & 16.5 & 2.5 & -0.6 & 52.7 \\
\hline United Kingdom & 13.3 & 0.6 & 2.8 & 18.6 & 7.4 & 1.3 & 1.5 & 38.0 \\
\hline United States & 10.6 & 0.4 & 3.7 & 14.4 & 9.2 & 3.2 & -2.4 & 29.9 \\
\hline Euro area & 16.6 & 1.4 & 4.1 & 19.8 & 10.5 & 2.5 & 0.3 & 44.8 \\
\hline $\mathrm{OECD}^{1}$ & 12.5 & 0.9 & 3.7 & 16.9 & 9.3 & 3.7 & -1.0 & 36.6 \\
\hline
\end{tabular}

1. Weighted average

Source: OECD, revised GFS (Government Financial Statistics) accounts. 
Figure 3. Main components of primary general government outlays ${ }^{1}$

\section{A. Hungary}

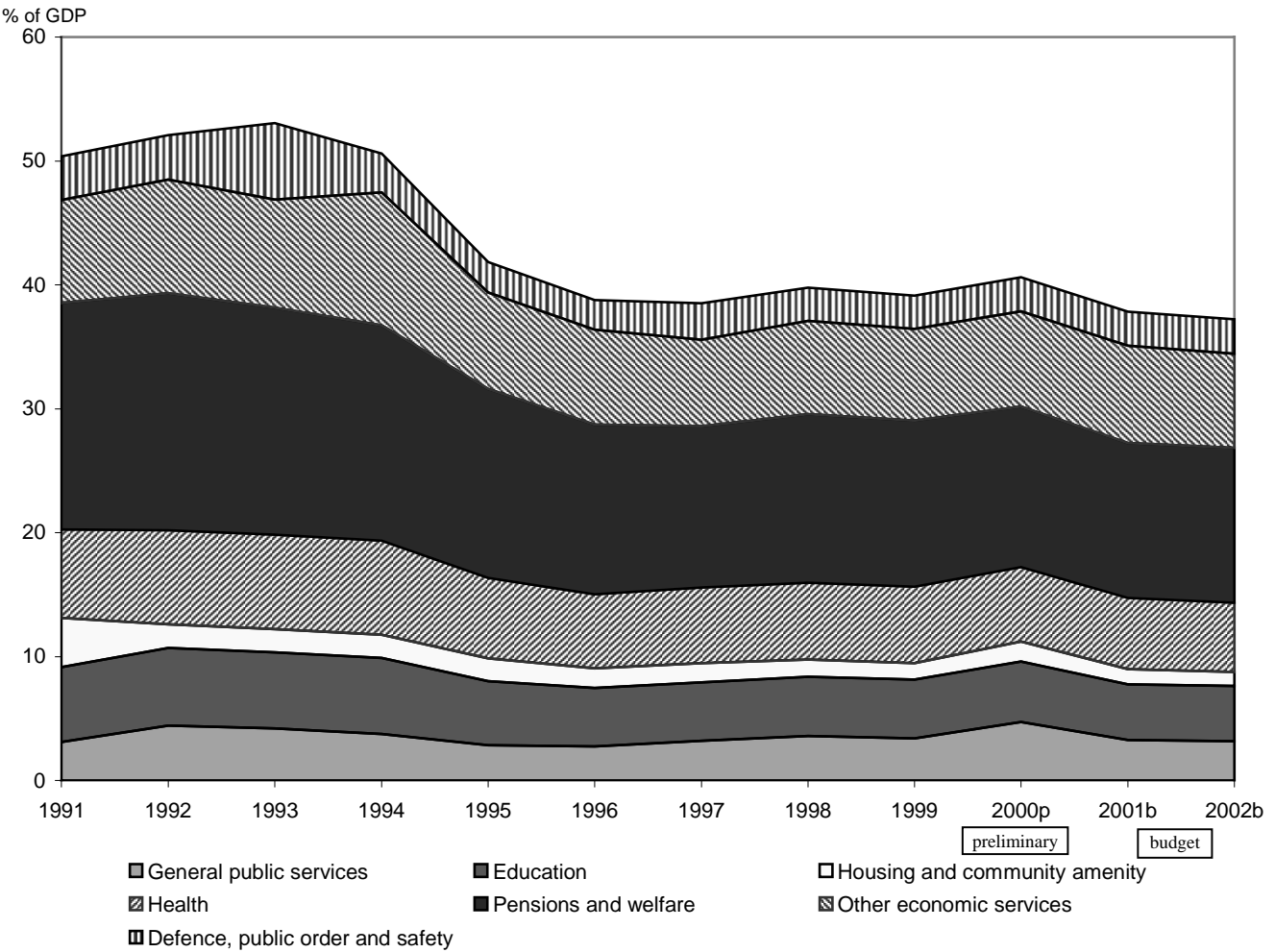

B. International comparison, $1995^{2}$ $\%$ of $\mathrm{GDP}^{3}$

\begin{tabular}{lrrrrrrr}
\hline & $\begin{array}{r}\text { General } \\
\text { public } \\
\text { services }\end{array}$ & Education & $\begin{array}{r}\text { Housing } \\
\text { and } \\
\text { community } \\
\text { amenity }\end{array}$ & Health & $\begin{array}{r}\text { Pensions } \\
\text { and } \\
\text { welfare }\end{array}$ & $\begin{array}{r}\text { Economic } \\
\text { services } \\
\text { and } \\
\text { subsidies }\end{array}$ & $\begin{array}{r}\text { Defence, } \\
\text { public } \\
\text { order and } \\
\text { safety }\end{array}$ \\
\cline { 2 - 7 } Austria & 3.6 & 5.3 & 0.4 & 5.7 & 18.8 & 3.1 & 0.9 \\
Czech Republic (1997) & 2.3 & 4.5 & 0.4 & 6.2 & 12.1 & 5.7 & 1.6 \\
Denmark & 4.3 & 6.5 & 2.3 & 5.1 & 18.5 & 5.6 & 1.7 \\
France (1993) & 6.3 & 5.9 & 1.3 & 7.1 & 19.6 & 3.1 & 2.9 \\
Germany & 3.8 & 4.5 & 0.8 & 8.0 & 17.4 & 4.5 & 1.4 \\
Hungary (1998) & $\mathbf{4}$ & $\mathbf{4 . 4}$ & $\mathbf{0 . 8}$ & $\mathbf{5 . 2}$ & $\mathbf{1 2 . 5}$ & $\mathbf{5 . 4}$ & $\mathbf{1 . 0}$ \\
Italy & $\mathbf{4 . 3}$ & 4.5 & 0.0 & 5.3 & 17.9 & 4.6 & 1.7 \\
Japan & 4.8 & 3.8 & 2.9 & 5.6 & 9.9 & 5.3 & 0.9 \\
Korea & 3.6 & 3.6 & 0.1 & 1.8 & 1.7 & 3.7 & 2.9 \\
Portugal & 2.8 & 3.6 & 0.1 & 4.7 & 12.0 & 6.3 & 2.2 \\
Spain & 6.1 & 5.4 & 0.1 & 5.5 & 14.7 & 5.9 & 1.4 \\
Sweden & 8.5 & 4.8 & 0.2 & 5.7 & 19.1 & 3.4 & 2.3 \\
United Kingdom & 3.1 & 6.6 & 2.1 & 5.7 & 3.3 & 3.2 \\
United States & 2.2 & 4.6 & 2.1 & 5.7 & 13.5 & 3.3 & 2.8 \\
\hline
\end{tabular}

1. The sum of the components is not equal to total primary outlays since only the main components are shown in the graph.

2. This comparative functional decomposition of government expenditures is only available for the year 1995 for the majority of countries. 3. Expenditures by function may not add up to total expenditure as these are derived from different sources. In particular, expenditures

by function refer to fiscal years and total expenditure to calendar years. Total expenditure is net of capital transfers received.

4. All the Hungarian figures except for education, health and the unemployment component of pensions and welfare come from the GFS data provided by the Hungarian Government.

Source: OECD: National Accounts, Social Expenditure Database, Education at a Glance and Survey of Current Business; Ministry of Finance of the Czech Republic; Ministry of Finance of Hungary. 
Figure 4. Government employment and wages

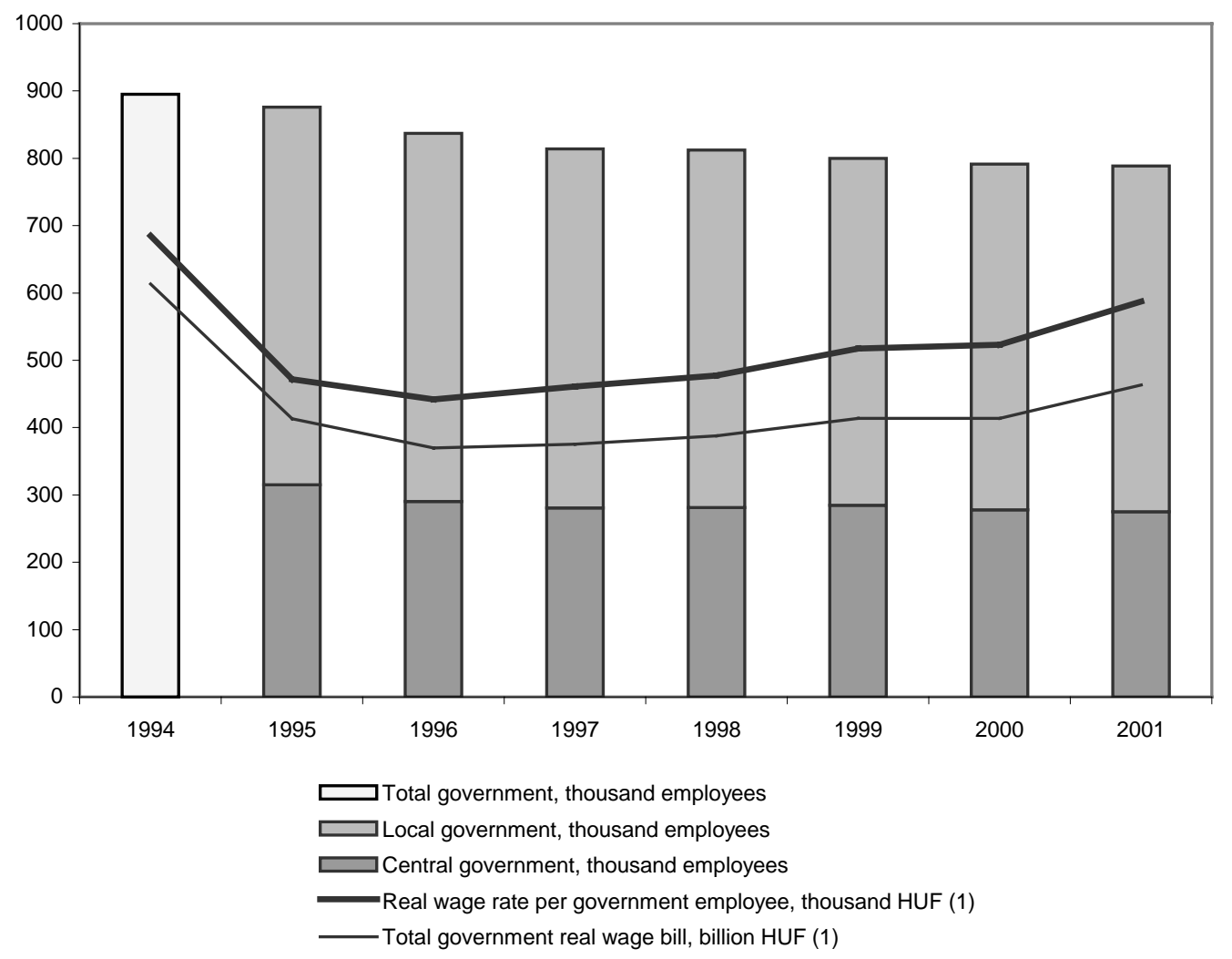

1. Deflated by CPI, base year 1995.

Source: Central Statistical Office.

\section{Budget procedures need to be strengthened further}

5. Hungary has made an important progress in improving the transparency and accountability of its public finance system. The budget which, at the beginning of transition had "failed to secure aggregate fiscal control and even to provide information about the ways public moneys were spent" ${ }^{\text {"7 }}$ has been transformed, through successive institutional innovations ${ }^{8}$ into a much improved fiscal management system which matches the fiscal practices of several other OECD countries. The relatively comprehensive coverage of the budget, together with clear procedures which govern its preparation, approval, implementation and audit, underlie this progress. Achievements in each area have been considerable but design features and actual practice also reveal certain shortcomings. The scope of the budget, its preparation procedures, its implementation techniques, and its auditing and closing principles are examined below with a view to increasing the efficiency of resource allocation and improving the room for public sector consolidation.

7. Polackova et al. (1999).

8. The Public Finance Act of 1992, its Amendment in 1996, and the Government Decree For the Rationalisation of Public Finances of 2000 have shaped the budget procedures and institutions. 


\section{Coverage and transparency of the budget}

6. The Public Finance Act defines general government comprehensively, in accordance with international standards ${ }^{9}$. The boundaries of public finance activities included in the budget encompass the accounts of the central government, of social security funds (the health insurance and pension funds), two extra-budgetary funds (see Box 1) and local governments. Local governments have limited own revenues, are funded in a large proportion from the central budget and "shared" (redistributed) personal income tax revenues, and are responsible for carrying out most public services, while 910 central budget institutions (CBIs) and more than 13000 local budget institutions ${ }^{10}$ (LBIs) are identified and financed individually.

\section{Box 1. Extra-Budgetary Funds}

The role of extra-budgetary funds (XBFs) has been considerably reduced. Their number dropped from 35 to 2 at the occasion of the 1995 reforms. In contrast to other OECD countries the pension and health insurance funds have always remained sub-sectors of the general government and are governed by the same law as the central budget, but retain an administrative identity to facilitate their multi-yearly management. The two XBFs are the Central Nuclear Financial Fund (CNFF) and the Labour Market Fund (LMF). The LMF, mainly financed by the earmarked contributions from employers and employees, provides benefits to the unemployed and is a main financial resource for implementing Active Labour Market Programs (ALMPs). Though they are subject to the same budget process and parliamentary approval as the state budget, the management of XBFs are allowed to depart from budgetary rules. Both funds are authorised to keep cash assets, cumulate them over years and may ask for liquidity loans from the Treasury; they can also carry over their total surplus between budget exercises. In fact, LMF has accumulated HUF 26.3 billion from higher than budgeted revenues and lower than budgeted expenditures in 2000 and unspent residuals from the years before 2000. XBFs are allowed to allocate spending at their full discretion and commit higher-than-budgeted expenditures if they can fund them within the stipulations of the respective laws establishing them. Due to the drastic reduction in their number, however, present $\mathrm{XBF}$ expenditures account for no more than 1.2 per cent of total government spending.

7. The budget is prepared, and its implementation monitored, in accordance with Government Financial Statistics (GFS) standards, i.e. on a cash basis. Additional non-cash obligations are also included in order to keep the contingent liabilities of the government under control. Notably, official loan guarantees are made subject to strict quantitative limits. Budget provision is made for calls on these guarantees. There is an overall ceiling to the total amount of cover given to individual enterprises in terms of a percentage proportion of total budget expenditures, and a ceiling in nominal forint terms for government financial institutions such as Eximbank, the Export Credit Guarantee Institution, the SME Credit Guarantee Institution, the Rural Credit Guarantee Foundation and the Hungarian Development Bank. Budget provisions for government financial institutions are made on a risk-weighted, actuarial basis, based on confidential risk analyses, while expected call rates on guarantees are published. The overall ceiling on individual guarantees which was set at 2.2 per cent of budget expenditures in law, was raised to 3 per cent via an amendment to the budget law of 2001 in December 2001 -- mainly in order to support large sport infrastructure projects.

8. The guarantees to the SME financing activities may cover up to 90 per cent of SME credit risks in selected commercial loans. Additional guarantees were made available to the Hungarian Development Bank, under separate limits granted under the 2001 budget amendment, for its motorway financing

9. $\quad$ See $\operatorname{IMF}(2001 b)$.

10. These comprehend specialised service providing organisations including kindergartens, schools, clinics, garbage collection services etc. 
activities which have limited reimbursement prospects (see below). The central government also covers the loans extended in Hungary by international public financial institutions. At the end of 2001, the outstanding amount of individual guarantees was almost HUF 170 billion (1.1 per cent of GDP), the outstanding amount of all guarantees reaching HUF 803 billion (5.2 per cent of GDP). ${ }^{11}$ Some of the recently extended guarantees may worsen the quality of the guarantee portfolio which was, traditionally, conservatively managed. If the new risks prove higher than those of the traditional guarantees, budget provisions would need to be increased (Table 1).

9. The expenditures and liabilities of the government-owned financial and non-financial institutions constitute the single most important soft spot in the coverage and transparency of the general government accounts. Privatisation has narrowed down this sector and has curbed the scope for policy driven spending by such organisations. ${ }^{12}$ In addition, explicit government guarantees and counterguarantees to this sector are capped. Still, recent developments point to persisting and in certain instances growing resource commitments by off-budget quasi-fiscal entities. They are limited in number but each of them has become very active. The most important cases are:

- The state holding company APV, which is in charge of privatisation but continues to run a large portfolio of companies where it reinvests its privatisation income;

- The Hungarian Development Bank (MFB), which finances the motorway development programme but also invests in a range of low revenue companies; and

- The state railway company MAV which invests, including via direct borrowing, 0.3 per cent of GDP per year, while running recurrent operating losses (which approached 1 per cent of GDP in some of the previous years and amounted to 0.2 per cent of GDP in 2001).

10. There are also off-budget municipal holdings and utility companies, active in a wide variety of areas including housing, many of which accumulate operating losses.

11. In principle, GFS methodology includes the reporting of policy loans as budget spending, but this does not apply to loans by off-budget institutions. ${ }^{13}$ Only direct government transfers to APV are included in the budget, but APV's own activities are only reported in a regular annex to the overall budget report. Its full revenues, expenditures and deficit, which are quasi-fiscal, are transparent but not integrated in the general government accounts. As transfers, guarantees and counterguarantees granted by the budget to these government financial institutions do not delineate their actual spending -- they have significant own revenues and can borrow and spend on their account -- it is justified to include their policy-driven expenditures, revenues and deficits in the budget after netting out their mutual transactions (Table 2). The Public Finance Act has been amended in 2001, mandating that these units provide budgetary authorities with a quarterly report compatible with ESA 95 principles. The Ministry of Finance is authorised to designate by decree the entities subject to this obligation and to fix the scope of reporting. There appears to be some resistance to this new reporting principle, and practice will reveal the efficacy of this amendment Box 2).

11. Actuarial risk calculations are available only for guarantees to government financial institutions.

12. All banks but two have been privatised and business enterprises still controlled by the government represent 5 per cent of total employment.

13. The "lending and repayments" reported in the 1999 closing budget accounts were nil. 


\section{Box 2. The measurement of fiscal stance by cash and accrual-based accounts}

The OECD Economic Survey of Hungary 2000 highlighted the need for both internationallycomparable and economically meaningful general government accounts. Despite the progress achieved by the authorities, the situation remains somewhat unsatisfactory. In addition to its official accounts based on the GFS methodology, the government has presented rudimentary fiscal data based on the ESA95 methodology in its 2001 Pre-accession report and Notification report to the European Union. Another source for accruals-adjusted data is the National Bank of Hungary (NBH) that estimates balances of the general government sector by adjusting the GFS fiscal data to obtain, for analytical purposes, a deficit measure reflecting the macroeconomic impact of changes in the fiscal stance.

Both estimates of the accruals-based balances indicate that a significant fiscal loosening took place in 2001. The GFS primary balance declined from 1.5 per cent of GDP in 2000 to 0.8 per cent in 2001 implying a fiscal stimulus of 0.7 per cent of GDP. The Central Bank's Quarterly Report on Inflation published in February 2002, taking account of off-budget expenditures, indicates a significantly stronger stimulus measured by the change in primary balance, amounting to 2.5 per cent of GDP. Concerning 2002, the GFS primary balance according to the government will decrease slightly to 0.7 per cent of GDP, implying no significant tightening, whereas the NBH projects an adjusted primary balance deteriorating by a further 0.7 per cent of GDP.

The principal difference between the two available accruals-based measures is the absence of the quasi-fiscal activities of the Hungarian Development Bank and of the National Motorway Corporation in the government's ESA95 data, but their inclusion in the NBH estimates. The OECD Secretariat's estimation of the fiscal stance is closer to the latter because it incorporates most of the NBH adjustments to the official GFS accounts (see Annex I).

12. Another weakness of the GFS based government accounts is the lack of a depreciation account; consequently the depletion of the public capital stock is not measured. General government investment is reported on a gross basis, and therefore includes the corresponding amount of depreciation, but current spending is reported at a lower level. Actual depreciations which are lost from sight have been estimated at above 4 per cent of GDP yearly. ${ }^{14}$ This imperfect accounting for depreciation makes the constitution of capital reserves more difficult and appears as an additional source of strain in the maintenance and management of public capital stock ${ }^{15}$-- an important issue today.

14. The Central Statistical Office calculated the consumption of fixed capital in 2000 at HUF 556 billion, or 4.2 per cent of GDP. The IMF had previously estimated the economic depreciation rate of the public capital stock at 3 per cent yearly.

15. In 2000 the OECD Territorial Development Service estimated that local government investments remained below replacement rates. 


\section{Table 1. Growth and risks of loan guarantees}

\begin{tabular}{|c|c|c|c|c|c|c|c|c|}
\hline & \multicolumn{2}{|c|}{ Liability ceiling $^{1}$ (HUF billion) } & \multicolumn{2}{|c|}{$\begin{array}{l}\text { The use of liability ceiling } \\
\text { (HUF billion) }\end{array}$} & \multicolumn{2}{|c|}{$\begin{array}{l}\text { Risk (estimates, per } \\
\text { cent) }\end{array}$} & \multicolumn{2}{|c|}{$\begin{array}{l}\text { Value at risk } \\
\text { (HUF billion) }\end{array}$} \\
\hline & 1998 & $2001^{2}$ & 1998 & $2001^{2}$ & 1998 & 2001 & 1998 & 2001 \\
\hline Within per cent limit & 28 & 135.2 & 25.6 & 106.9 & 30 & & 40 & \\
\hline Beyond per cent limit & 16 & 67 & 37 & 114.8 & 5 & & 1.8 & \\
\hline \multicolumn{9}{|l|}{$\begin{array}{l}\text { Guarantees to activities of specific } \\
\text { institutions }\end{array}$} \\
\hline MFB - Hungarian Development Bank & 80 & 480 & 50 & 124.5 & 5 & & 2.5 & \\
\hline Eximbank & 75 & 185 & 50 & 133.7 & 7 & & 3.5 & \\
\hline MEHIB - Export-import insurance company & 185 & 250 & 110 & 74.8 & 8 & & 8.8 & \\
\hline Hitelgarancia RF- Credit Guarantee Company & 55 & 150 & 42 & 109.4 & 5 & & 1.0 & \\
\hline Rural Credit Guarantee Foundation & 33 & 45 & 10 & 11.4 & 5 & & 0.5 & \\
\hline $\begin{array}{l}\text { Guarantees to International Financial } \\
\text { Institutions }\end{array}$ & Unlimited & Unlimited & Unlimited & 181.8 & & & & \\
\hline Total & 472 & 1312.2 & 324.6 & 857.3 & & & & \\
\hline
\end{tabular}

1. The total amount of new guarantees issued in respective years in case of individual guarantees, the total outstanding amount of guarantees as of year-end in case of Guarantees to activities of specific institutions.

2. 2001 figures are as of Budget Amendment.

Source: Hungarian authorities, Polackova et al. 
Table 2. Expenditures of selected state-owned companies

\begin{tabular}{|c|c|c|c|c|}
\hline & $\mathrm{MAV}^{1} 2000$ & $\mathrm{MFB}^{2} 2000$ & APV $^{3} 2001$ plan & Total \\
\hline Expenditures, HUF billion & 201.4 & 319.9 & 100.5 & 621.8 \\
\hline $\begin{array}{l}\text { Proportion of general government current } \\
\text { expenditure in } 2000 \text {, per cent }\end{array}$ & 3.7 & 5.8 & 1.8 & 11.3 \\
\hline $\begin{array}{l}\text { Proportion of general government investment in } \\
2000 \text {, per cent }\end{array}$ & 36.9 & 58.6 & 18.4 & 113.9 \\
\hline Proportion of GDP in 2000 , per cent & 1.5 & 2.4 & 0.8 & 4.8 \\
\hline
\end{tabular}

1. Direct costs and other expenses.

2. Change in equity investments, amount of loans and other assets.

3. Investment activity, reorganisation and operational costs.

Source: OECD.

13. The Ministry of Finance has initiated work for preparing accrual-based accounts. ${ }^{16}$ The main differences in Hungary between cash- and accrual- based accounts concern: i) unspent reserves transferred between budget exercises and accruing partly in the year of origin; ii) accrued but not entirely collected tax revenues $;{ }^{17}$ iii) accounts payable by central and local budget institutions; iv) interest accruing on public debt; v) social security contributions of government employees (accruing both as government expenditures and revenues, while they are netted out in cash-based accounts); and vi) debt assumption over financial and non-financial institutions (which does not show up in cash accounts). Accrual-based accounting generally leads to a mark-up of expenditures, and the mark-up is likely to be significant in Hungary (Table 3). This technique is only partly applied in other OECD countries, still it would contribute highly to the content of government accounts. ${ }^{18}$

16. According to the system of national accounts (SNA), and their European specifications under the European system of accounts (ESA 95) norms.

17. These have two components: tax arrears (declared but not paid taxes) and tax evasion (anticipated but not declared taxes). The Ministry of Finance has initiated a project to estimate and monitor both sources of tax losses -- an estimate of which is not available at present. Cash-based accounts have an element of caution in this respect, as they safeguard against the registration of unpaid taxes as (potentially fictitious) revenues.

18. Fiscal reporting to the European Union will likely quicken these efforts, as reporting will need to be done according to ESA 95 standards. Hungary has already submitted tentative accrual-based budget forecasts to the EU in spring 2001, with a new set of such numbers planned for spring 2002. In contrast, the use of accrual accounts in domestic budget documents is not yet in sight. 


\section{Table 3. Differences between cash and accrual-based accounts}

As per cent of GDP

\begin{tabular}{|c|c|c|c|c|c|c|c|c|c|}
\hline & \multicolumn{3}{|c|}{2000} & \multicolumn{3}{|c|}{2001} & \multicolumn{3}{|c|}{2002} \\
\hline & $\begin{array}{c}\text { Cash-based } \\
\text { GFS }^{1}\end{array}$ & $\begin{array}{c}\text { Accrual- } \\
\text { based SNA }\end{array}$ & $\begin{array}{c}\text { OECD } \\
\text { adjusted }^{3}\end{array}$ & $\begin{array}{c}\text { Cash-based } \\
\text { GFS }^{1}\end{array}$ & $\begin{array}{c}\text { Accrual- } \\
\text { based SNA }\end{array}$ & $\begin{array}{l}\text { OECD } \\
\text { adjusted }^{3}\end{array}$ & $\begin{array}{c}\text { Cash-based } \\
\text { GFS }^{1}\end{array}$ & $\begin{array}{c}\text { Accrual- } \\
\text { based SNA }\end{array}$ & $\begin{array}{l}\text { OECD } \\
\text { adjusted }^{3}\end{array}$ \\
\hline Total revenues & 43.0 & 45.9 & 44.5 & 41.7 & 43.4 & 44.0 & 38.5 & 42.0 & 43.8 \\
\hline Primary revenues & 42.1 & 45.2 & 43.1 & 41.1 & 43.0 & 42.9 & 38.1 & 41.7 & 43.0 \\
\hline Total expenditures & 46.4 & 48.9 & 47.5 & 45.1 & 47.7 & 49.1 & 41.7 & 45.5 & 49.3 \\
\hline Primary expenditures & 40.3 & 43.0 & 41.7 & 40.1 & 42.6 & 44.2 & 37.3 & 40.9 & 44.6 \\
\hline General government balance & -3.1 & -3.1 & -3.0 & -3.4 & -4.3 & -5.2 & -3.2 & -3.5 & -5.5 \\
\hline $\begin{array}{l}\text { Primary balance of the general } \\
\text { government }\end{array}$ & 2.2 & 2.2 & 1.4 & 1.0 & 0.4 & -1.3 & 0.8 & 0.8 & -1.6 \\
\hline
\end{tabular}

1. Official data, Ministry of Finance.

2. ESA 95 estimation of the Pre-Accession Economic Programme.

3. These estimates consolidate certain off-budget expenditures and adjust some cash items into accruals; see Box 2 on the details of methodology.

Source: OECD. 
14. To improve the transparency of the budget, additional information is provided on tax expenditures at the end of the budget year, a feature not available in many OECD countries. This is an ex post report however, and ex ante expenditure estimates are not completely included in the draft budget. The draft budget contains a list of allowances and exemptions from corporate and personal income taxes (Table 4).

Table 4. Tax expenditures ${ }^{1}$

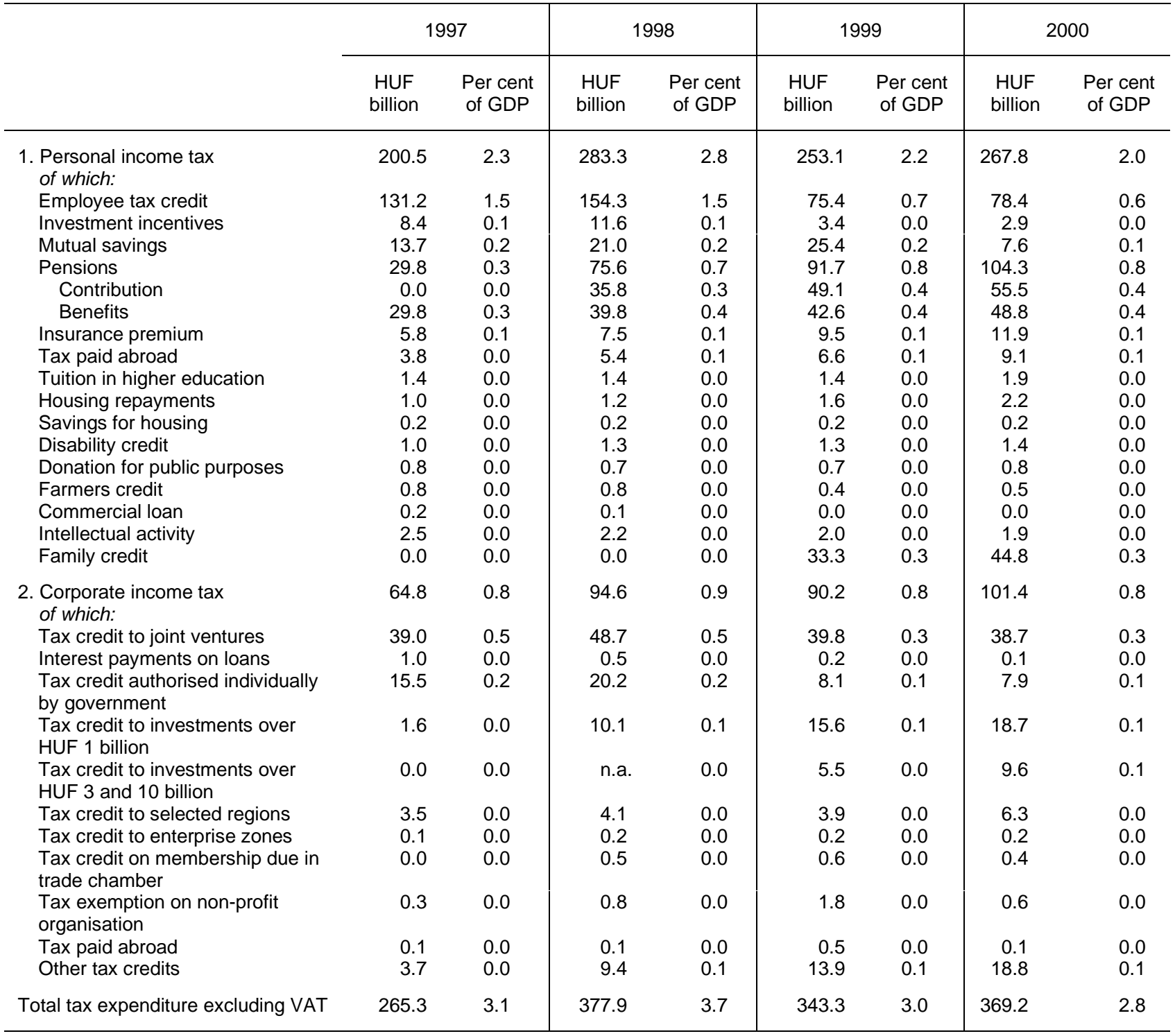

1. The figures are derived from declaration of tax paid. Thus they do not include tax-exempted income and income subject to the preferential rates.

Source: The Hungarian tax collection agency. 
15. State aids have been made transparent following a European Union recommendation. Information is reported on an ex-post basis and shows the large share of transport and pharmaceutical subsidies. ${ }^{19}$ The continuing significance of capital transfers (equity investments) in government-controlled enterprises is also noticeable (Table 5).

Table 5. State aids ${ }^{1}$

\begin{tabular}{|c|c|c|c|c|c|c|c|c|}
\hline & 1993 & 1994 & 1995 & 1996 & 1997 & 1998 & 1999 & 2000 \\
\hline & \multicolumn{8}{|c|}{ Per cent of GDP } \\
\hline General government & 5.9 & 7.0 & 6.0 & 5.9 & 5.2 & 7.6 & 7.2 & 7.4 \\
\hline $\begin{array}{l}\text { Central budget } \\
\text { of which: }\end{array}$ & 3.4 & 4.0 & 3.5 & 3.3 & 2.9 & 3.3 & 4.0 & 4.7 \\
\hline Agricultural subsidy & 0.0 & 1.7 & 1.3 & 1.3 & 1.0 & 1.1 & 1.2 & n.a. \\
\hline Railway production subsidy & 0.0 & 0.0 & 0.0 & 0.7 & 0.7 & 0.7 & 0.7 & 0.5 \\
\hline $\begin{array}{l}\text { Indirect subsidies to households } \\
\text { of which: }\end{array}$ & 0.9 & 0.8 & 0.8 & 0.8 & 0.8 & 0.7 & 0.8 & 0.6 \\
\hline Railway transport & 0.2 & 0.2 & 0.1 & 0.2 & 0.2 & 0.2 & 0.2 & 0.2 \\
\hline Long-distance bus & 0.2 & 0.2 & 0.2 & 0.2 & 0.3 & 0.3 & 0.3 & 0.3 \\
\hline Local transport & 0.2 & 0.2 & 0.2 & 0.3 & 0.3 & 0.3 & 0.2 & 0.2 \\
\hline Interest subsidies via banks & 0.3 & 0.1 & 0.2 & 0.1 & 0.1 & 0.0 & 0.0 & 0.0 \\
\hline Capital transfers to enterprises ${ }^{2}$ & 0.1 & 0.2 & 0.3 & 0.6 & 0.4 & 1.8 & 0.9 & 1.9 \\
\hline Extra-budgetary funds & 0.5 & 0.9 & 0.5 & 0.1 & 0.2 & 0.2 & 0.1 & 0.1 \\
\hline $\begin{array}{l}\text { Social security funds } \\
\text { of which: }\end{array}$ & 1.5 & 1.6 & 1.5 & 1.5 & 1.4 & 2.0 & 1.9 & 1.9 \\
\hline Medicine subsidies & 1.4 & 1.4 & 1.3 & 1.2 & 1.2 & 1.2 & 1.2 & 1.2 \\
\hline Local governments & 0.4 & 0.5 & 0.5 & 0.5 & 0.4 & 0.4 & 0.4 & 0.4 \\
\hline APV & & & & 0.6 & 0.3 & 0.4 & 0.8 & 0.4 \\
\hline
\end{tabular}

1. State aid includes the capital transfers which are recorded as capital outlays in the SNA.

2. Capital transfers to enterprises in 1998 include the capital injection of HUF 132 billion to Postabank.

Source: Ministry of Finance.

19. The final distribution and incidence of these transport and pharmaceutical transfers between enterprises and the households receiving their output at lower prices (i.e. public transportation and pharmaceutical products) is not known. 


\section{The preparation of the budget}

16. After successive reforms, budget preparation now follows a rigorously defined schedule (Box 3).

\section{Box 3. The schedule of budget preparation}

The budget preparation for the following year begins with the Minister of Finance issuing, by mid-April, guidelines which include "spending and deficit targets as a proportion of GDP" for the budget year, together with background forecasts for the following two years. These guidelines are adopted by the government by mid-May, ${ }^{1}$ before line ministries submit their budget requests to the Ministry of Finance during the summer months. The Ministry of Finance evaluates and negotiates them bilaterally with the line ministries before submitting a draft budget to the cabinet by end-August. The cabinet considers and approves the draft budget and submits it to the Parliament by end-September. The volume budgets of line ministries, in 28 chapters, together with a "three years prognosis" outlining forecasts for the following two years are formally submitted (although actual discussion begins earlier) to the Parliament by mid-October. The main fiscal aggregates and the budget chapters are first approved by a parliamentary resolution in November, before details are discussed and the final central government budget is voted normally by the end of the year. ${ }^{2}$ It is only at this stage that local government budgets, funded more than half by the central budget, are finalised and voted by municipal councils by end-March -- three months into the year they apply to. Local budgets include varying amounts of own revenues, including local taxes, service fees, asset sales and bank borrowing, which is capped by municipal law. ${ }^{3}$ Given these additional revenue sources, expenditures of local budgets may exceed the amounts forecasted in the general government budget. Furthermore, once they are voted by local bodies, the central government and Parliament have no leverage on them, so that genuine expenditure control problems can arise at the tail end of quite an intensive process. The Act on Public Finances also authorises budget procedures' taking place once every two years, leading to a bi-annual budget as was the case in 2001-02.

1. June in election years. Most recently the budget guidelines have not been endorsed by Parliament but were approved only by the government.

2. If the budget is not voted by end-December, the Minister of Finance establishes interim limits on expenditures on the basis of budget appropriations of the previous year.

3. Municipalities are authorised to borrow yearly up to 70 per cent of their net (after interest payments) own revenues.

17. A distinct feature of this finely orchestrated ${ }^{20}$ process is the low-key political character of the initial budget outlines. This document, which sets the stage for the entire three-year period is prepared in reference to the government programme but is not backed formally by a visible and binding policy statement. ${ }^{21}$ The basic objective of public spending remains therefore inarticulate and/or implicit. The lowkey character of the procedure may be functional in certain respects, as it preserves a room of manoeuvre for subsequent budget negotiations within the government and Parliament. However, it also amounts to a lack of strong prioritisation as a disciplining strategic framework.

20. The efficacy of the process supposes the timely and proper execution of interdependent steps. In recent budget exercises some steps had to be curtailed (the scope of certain budget documents fell short of the initial design). These shortcomings can be seen as teething problems.

21. See, on the importance of this element of the budget process, P. Atkinson and P. Van den Noord (2001) and OECD (2001h). 
18. Lack of strategic foundation for the guidelines is accentuated by the non-binding character of the three-year (budget year plus two following years) framework which accompany them. This three-year framework constitutes an important innovation introduced in 1997, which potentially provides a strategic perspective to the budget. However, it is of little or no practical importance in the budget process. The three-year outline issued in April is not binding for the 'three year prognosis' formulated in October. In the recent past, there have been important differences between the two which have been little noticed and discussed, as these frameworks are anyway perceived as not operational. ${ }^{22}$ Such a status is not supportive of a strategic approach, where important shifts in public expenditures can successfully be introduced only in a multi-year framework. ${ }^{23}$

19. The acquired legal rights of beneficiaries make the multi-year forecasts particularly important. Entitlements under the social security system generate the so-called "mandatory expenditures", which are a formal contingent liability of the government for the years to come, and constitute in principle an exogenous constraint on future budgets in the absence of amending legislation. ${ }^{24}$ The expected expenditures of social security (pension and health) funds can then be calculated in a long time horizon, with the help of well-developed models which are also available in Hungary. However, the government happens to add additional elements to parametric formulas year after year, as has been the case with the calculation of pension benefits, ${ }^{25}$ of health benefits ${ }^{26}$ and of pharmaceutical consumer subsidies. ${ }^{27}$ Such year-on-year changes transform "mandatory expenditures" into actually "discretionary" spending between budget exercises. This change of status facilitated their upward drift in the past -- with the notable exception of 1995 where benefit parameters were radically revised downward. Multi-year budget frameworks would made discretionary variations in benefits less likely, while allowing upward adjustments in accordance with improving economic circumstances or an explicit change in priorities.

20. In 2000 the government introduced a two-year budget voted as an integrated package by the Parliament, to be applied in 2001-02. This exercise turns the second year of the three-yearly budget projections into actual appropriations, and may in principle be seen as a step toward multi-year budgeting. However, actual practice did not fully bear this out. Multiple departures from the 2001 budget law

22. In 2000 for example, for the purposes of the 2001-2002 budget, the Parliament did not discuss the macroeconomic framework as it did not approve the budget guidelines. The government decided to keep the guidelines prepared for the 2000 budget.

23. Otherwise, in the experience of many countries and except in extreme crisis situations, resource shifts meet strong political and societal resistance. If resource shift proposals are perceived as "temporary" within a short-term yearly budget, resistance may reinvigorate and reforms may stall.

24. According to Ministry of Finance estimations in 2001, the share of mandatory expenditures in an intermediate sense (including health expenditures, old-age pensions, social welfare transfers, transport and pharmaceutical subsidies and debt servicing costs, but excluding government employees' salaries) amounted to 53 per cent of general government expenditures in 2001. If health expenditures and pharmaceutical subsidies are excluded the proportion diminishes to 45 per cent.

25. In December 2000 the government announced a 2.6 per cent additional one-off increase in old-age pensions. A similar augmentation of 1.5 per cent was also granted in December 2001. The law authorises both increases: additional pension increases must be carried out in November (with retroactive effect as of 1 January the same year) if expectations on CPI and net wage increase for the current year exceed by at least 1 per cent the projections used in the calculation of the rate of pension augmentation in the beginning of the year. This was the case in both 2000 and 2001.

26. Health expenditures are de facto rationed, and their level depends on budget resources available. They are therefore, from an economic viewpoint, not exogenous but endogenous to the budget. See Orosz and Burns (2000).

27. If regulated pharmaceutical prices rise there are upward pressures on pharmaceutical subsidies. 
(Chapter II) tended to erode the practical relevance of the second year draft. The transparency was also reduced in the first year by the growth of off-budget activities, amendments and spending drift. Although the 2001 budget law could be amended in the frame of the Report on the Fulfilment of the Annual Budget Law of 2000, the absence of a fully-fledged budget discussion at the end of 2001 raises concerns about the loosening of the legislative control over budget formation and execution.

21. Another source of weakness in the budget preparations is the fact that macroeconomic assumptions underlying the budget are not thoroughly examined and debated, both by the public opinion and the Parliament. They exist in draft budget documents but may prove overly optimistic, as they did in several OECD countries in 2000-02. The sensitivity of fiscal outcomes to domestic and international economic developments is not studied in detail as an input to budget discussions. ${ }^{28}$ For example, had such a sensitivity analysis been discussed, the fiscal impacts of the ongoing domestic and international downturn could have been better gauged. Short and medium-term budget projections -- those included in the domestic budget documents as well as projections submitted to the European Union partners in the context of accession talks -- would then have included alternative scenarios closer to more recent forecasts (Figure 5). ${ }^{29}$

22. Introducing cyclically-neutral (structural) fiscal objectives and targeting spending objectives in volume independently from the cycle, while letting the automatic stabilisers determine actual government revenues and deficits, might in principle help better address macroeconomic uncertainties. This approach may necessitate more macroeconomic information than presently available; notably on the potential growth rate of the economy and the revenue and expenditure elasticities of the budget to GDP growth. The post-transition Hungarian economy has not yet gone through an entire economic cycle so that the required empirical background information is limited. Still, developing this approach, even tentatively, and making the information on the structural and cyclical assumptions of budget forecasts public should be technically in reach today.

23. Another specific feature of budget preparation in Hungary has shorter-term consequences: Budget preparations are focused on the general government deficit as a percentage share of actual GDP, and, secondarily, on expenditure objectives as a percentage share of actual GDP. Such benchmarks permit updrift in the actual volume of revenues and expenditures when growth and inflation are higher than predicted -- as long as percentage targets for the deficit are respected. ${ }^{30}$ Notably, inflation windfalls have been a systematic source of additional revenues and expenditures in past budget exercises, usually of more than 1 per cent of GDP. The spending autonomy granted to central and local budget organisations, which are authorised to spend unplanned increases in their revenues, goes in the same direction. ${ }^{31}$ If "windfall revenues and spending" reach certain thresholds, ex post budget amendments become necessary, but the Parliament approved them in the past as long as percentage deficit targets were met.

28. Various scenarios are examined in the Ministry of Finance but not in the Parliament.

29. An alternative scenario available in the pre-accession economic programme was not significantly different from the baseline projection.

30. The elasticities to inflation of fiscal inflows and outflows are asymmetric in Hungary and create net taxation gains. Inflation having a more than expected impact on actual tax pressure, independently from output growth, diminishes the predictability of budget outcomes.

31. Share of own revenues, including user fees, in central and local budgetary institutions (CBIs and LBIs) can attain in certain cases up to $30-40$ per cent of their expenditures. 
Figure 5. Macroeconomic assumptions of budget forecasts

\section{A. GDP growth}

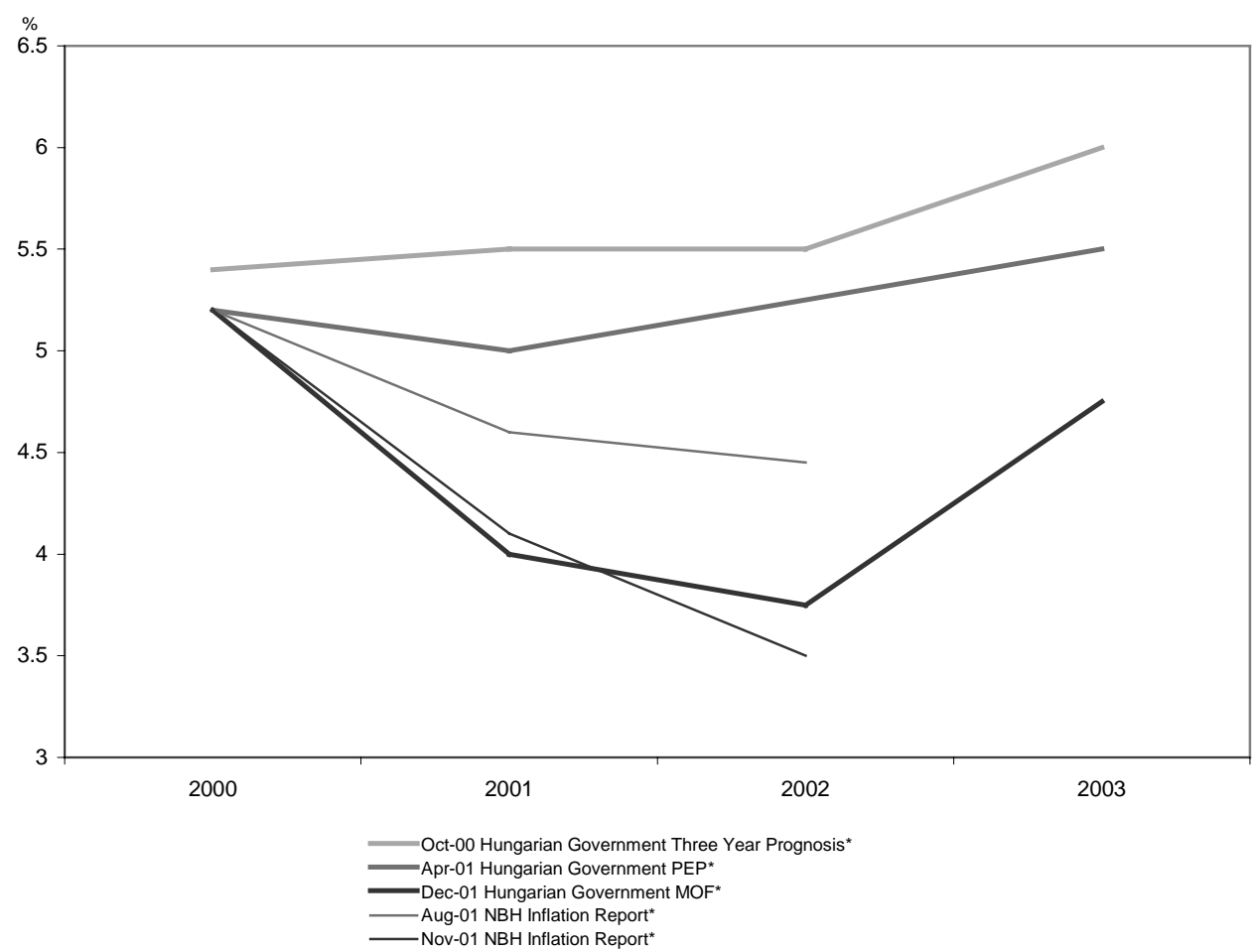

B. CPI inflation

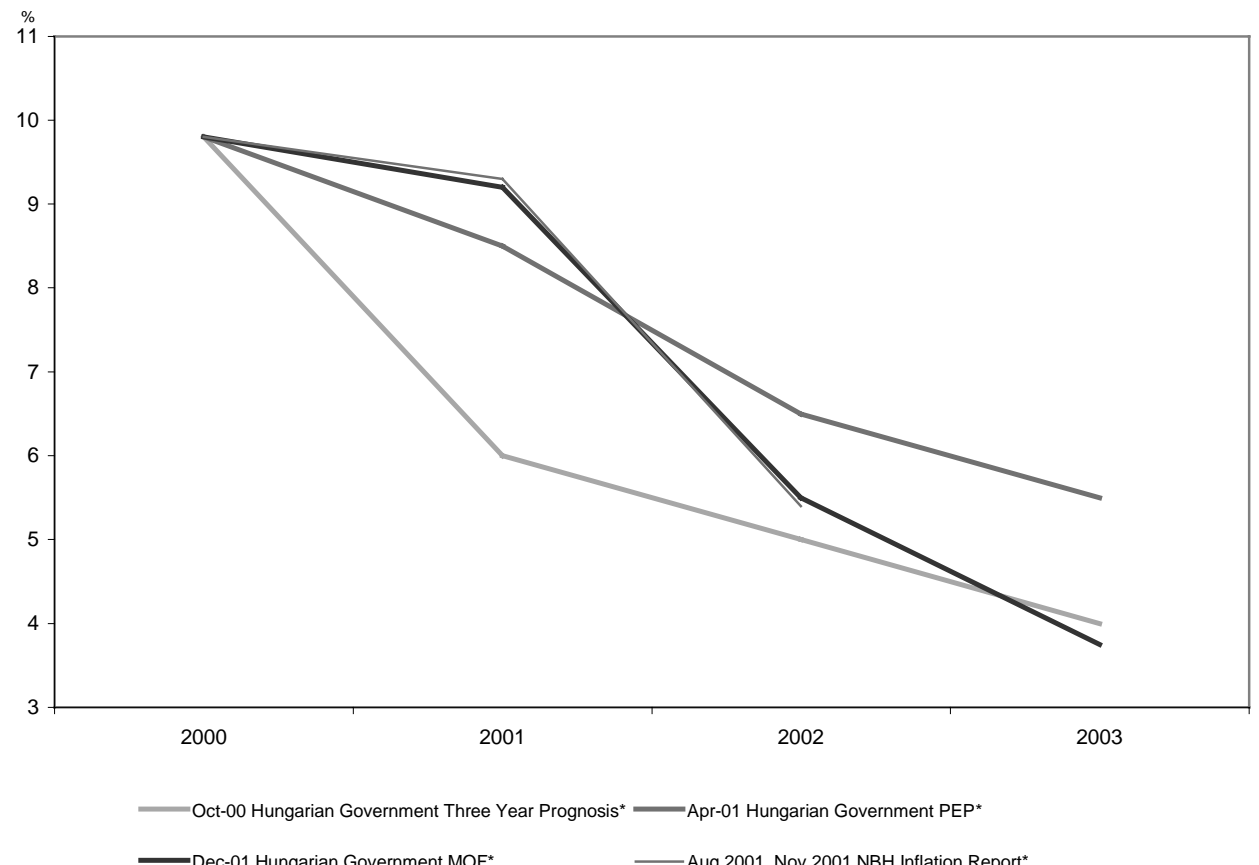

* The projections are the midpoints of the given range.

Source: Ministry of Finance (MOF); National Bank of Hungary; OECD; Pre-Accession Programme of the Republic of Hungary (PEP) April 2001. 


\section{The implementation and control of the budget}

24. Once the budget is voted, actual spending is carried out under the surveillance and operational management of the central Treasury. The Treasury was reorganised in 2001 into a Public Finance Office (PFO) and a Cash Management Office (CMO) reporting to the Minister of Finance. ${ }^{32}$ The PFO records all budget appropriations, proceeds to the planned disbursements, and check the compliance of operations with budget law and rules. It also enforces the proper application of public tender laws to the procurement of goods and services.

25. Most importantly, the CMO executes a corporate-type cash-management and treasury function, with monthly surveillance of the departures from planned cash-flows. It signals any unplanned drifts to the Minister of Finance who sets forward proposals to the government to tackle them by immediate cuts and freezes in discretionary expenditures. If such reductions reach more than 10 per cent of the appropriations concerned or 0.1 per cent of the total budget, the government has to report to the Parliament about them. If this does not suffice to ensure the achievement of the approved budget balance, a supplementary budget proposal becomes necessary. If the target balance is preserved however, no such action is needed. If overspending concerns mandatory expenditures (in pensions and health-related obligations for instance, where overspending has been frequent) parliamentary approval is not necessary.

26. Overall, this centralised system proves effective in the attainment of the deficit targets, but less so in the enforcement of budgeted revenue and expenditure volumes. The Public Finance Office has no authority to control the expenses of the local governments which are partly financed from local revenues, but can only check the proper utilisation of central government grants and territorial tax equalisation transfers. As central transfers represent up to 70 per cent of all municipal revenues, these rules give nevertheless a wide room for scrutiny to central authorities. From 2002, the PFO has also been authorised to control ex ante the regularity of the local government demands for Central Government transfers. The State Audit Office monitors the adherence to the legal borrowing caps by local governments (see below).

27. Tax revenues of municipal governments increased from a low base (Table 6), but the rise has been constrained by that of taxable incomes (and the readiness to pay more taxes) of local constituencies, and by some emerging competition between municipalities to attract mobile business investments. ${ }^{33}$ Asset sales and service concession revenues, which topped-up municipal incomes by as much as 10 per cent in the late 1990s, have come down, as marketable assets diminished and municipalities are banned from privatising the capital stock needed for "core services" (such as hospital and school buildings). In 2001 privatisation proceeds represented only 2.3 per cent of local revenues.

28. Local governments have not yet made full use of their -- rather strict -- borrowing rights (Box 4). The municipal credit market has grown more slowly than in other countries in the region. Beyond limited available funds from the financial market -- i.e. banks' and capital markets' reluctance to lend to municipalities in the absence of central government guarantees -- the availability of other funding sources also constrained this market. Today these alternative funding sources (including cheaper alternative sources from local privatisation revenues, central government grants, and, to a lesser extent, interest free

32. The Government Decree on the Reorganisation of Public Treasury of Autumn 2000, created three new agencies: a Public Finance Office (PFO) which took over most treasury functions, a Cash Management Office (CMO) and a Public Debt Management Agency. The Public Debt Management Agency was created in 1996 but was reorganised in joint-stock company form (presumably destined to facilitate flexible financing, hiring and staff management) in 2001. .... and maybe household settlements (OECD, 2001f). 
loans and interest rate subsidies from the central government) are in decline and increased banking competition has led the commercial banks to prospect the municipal market actively. It is important that borrowing remains proportional to the ability of local governments to generate additional revenues. As long as links of additional funding to local economic activity and output are secured, further investment would contribute to local development. From the viewpoint of the general government budget however, this may add to spending pressures and weaken overall fiscal restraint.

Table 6. The growing role of local taxes

Local government revenues by source as a percentage of total local revenues

\begin{tabular}{|c|c|c|c|c|c|c|c|}
\hline & 1995 & 1996 & 1997 & 1998 & 1999 & 2000 & 2001 \\
\hline Shared taxes & 12.2 & 11.3 & 12.0 & 14.0 & 13.7 & 15.5 & 16.0 \\
\hline PIT & 11.9 & 10.5 & 11.3 & 13.4 & 12.8 & 14.6 & 15.2 \\
\hline Vehicle tax & 0.3 & 0.7 & 0.7 & 0.7 & 0.8 & 0.8 & 0.7 \\
\hline Tax on land leasing & 0.0 & 0.0 & 0.0 & 0.0 & 0.1 & 0.1 & 0.1 \\
\hline Own current revenues & 19.4 & 24.7 & 26.8 & 29.4 & 30.8 & 30.8 & 31.2 \\
\hline Local taxes & 4.9 & 8.4 & 9.3 & 10.9 & 13.2 & 13.4 & 14.3 \\
\hline Fees and charges & 1.5 & 1.6 & 1.5 & 1.6 & 1.6 & 1.8 & 1.8 \\
\hline Fines & 1.1 & 1.2 & 1.7 & 1.8 & 1.7 & 1.9 & 1.5 \\
\hline Interest income & 1.4 & 1.7 & 2.8 & 2.6 & 2.1 & 1.8 & 1.3 \\
\hline Own revenues of LBIs & 8.7 & 8.4 & 8.0 & 8.5 & 8.3 & 8.0 & 8.2 \\
\hline Others $^{2}$ & 0.9 & 3.3 & 3.5 & 4.1 & 3.7 & 3.9 & 3.7 \\
\hline Capital revenue & 11.5 & 12.4 & 15.4 & 9.0 & 8.6 & 10.9 & 10.1 \\
\hline Sale of real assets & 5.5 & 4.5 & 4.3 & 3.8 & 4.0 & 4.6 & 4.1 \\
\hline Privatisation & 3.3 & 4.9 & 7.5 & 1.4 & 1.5 & 2.2 & 1.1 \\
\hline Accumulated revenues & 2.7 & 3.0 & 3.6 & 3.7 & 3.1 & 4.1 & 4.9 \\
\hline EU transfers & 0.0 & 0.0 & 0.0 & 0.0 & 0.0 & 0.0 & 0.0 \\
\hline Grants and transfers & 37.8 & 33.8 & 29.0 & 30.3 & 30.0 & 25.9 & 27.0 \\
\hline Normative grants & 29.4 & 24.1 & 21.5 & 20.2 & 19.2 & 15.9 & 16.2 \\
\hline Normative subsidies for fixed purposes & 0.0 & 0.8 & 1.0 & 1.4 & 2.0 & 3.8 & 3.5 \\
\hline Theatre grants & 0.3 & 0.4 & 0.4 & 0.4 & 0.4 & 0.3 & 0.3 \\
\hline Grants to disadvantaged localities & 0.9 & 0.6 & 0.6 & 0.6 & 0.8 & 0.8 & 0.8 \\
\hline (Centrally appropriated) other assistance & 4.1 & 5.5 & 2.4 & 4.0 & 3.9 & 1.0 & 1.6 \\
\hline Addressed and targeted grants & 3.1 & 2.4 & 2.6 & 2.6 & 2.6 & 2.9 & 3.7 \\
\hline Grants for regional equalisation & 0.0 & 0.1 & 0.6 & 0.8 & 0.6 & 0.6 & 0.5 \\
\hline Targeted, decentralised grants & 0.0 & 0.0 & 0.0 & 0.2 & 0.5 & 0.6 & 0.4 \\
\hline Specific grants & 17.4 & 17.6 & 16.8 & 17.2 & 17.0 & 16.9 & 15.7 \\
\hline Social security assistance & 16.1 & 15.4 & 14.0 & 14.2 & 14.1 & 13.9 & 13.1 \\
\hline Extra-budgetary fund transfers & 0.4 & 1.3 & 1.8 & 1.9 & 1.8 & 1.5 & 1.0 \\
\hline Funds from central budgetary organs & 0.8 & 0.8 & 0.9 & 1.0 & 1.1 & 1.5 & 1.5 \\
\hline Other budget supplements & 0.2 & 0.1 & 0.1 & 0.1 & 0.0 & 0.0 & 0.1 \\
\hline Total revenues (GFS basis) & 100.0 & 100.0 & 100.0 & 100.0 & 100.0 & 100.0 & 100.0 \\
\hline $\begin{array}{l}\text { Share of local government tax } \\
\text { revenues in total general government } \\
\text { revenues }\end{array}$ & 7.2 & 8.0 & 8.9 & 9.9 & 10.4 & 10.7 & n.a. \\
\hline
\end{tabular}

1. Based on the preliminary budget figures.

2. Includes value-added tax revenues from the sale of local government services, and revenues originating outside the government sector.

Source: Ministry of Finance. 


\section{Box 4. Borrowing rules for local governments}

Between 1990 and 1995 there were no formal rules concerning local government borrowing. In 1995, three villages were in default due to over-borrowing. In response, three separate acts were passed, creating a comprehensive legal framework on local government debt:

i) Debt service limits for local governments were integrated into the Local Government Act in 1996. Annual debt service is limited to "corrected own revenues", i.e. to 70 per cent of own local revenues subtracting the amount of short-term liabilities. Assets and revenues sources which may not be used to secure loans or bonds include: primary assets, normative grants, share of personal tax other state contributions, revenues received from state budget.

ii) The Local Government Bankruptcy Act of 1996 sets out the rules for restoring the ability to pay of local governments while providing effective legal protection to creditors. This sophisticated act explicitly waived all central government guarantees to municipal borrowing and prescribed bankruptcy procedures in case of defaults.

iii) Financial transparency and reporting requirements to accompany the issuance of municipal bonds were included in the Securities Act.

29. As a result of recent housing policies, new borrowing by municipalities for housing development purposes has been freed from borrowing caps. Municipalities have created local holdings and utility companies, including in the area of housing and other public services, whose revenues and expenditures are off-budget and therefore outside general government accounts. When such companies governed by commercial law can finance themselves on capital markets, they tend to develop their expenditures freely. According to one estimate, they are expected to initiate projects worth up to 2 per cent of GDP in early 2000 s. ${ }^{34}$ On the other hand, they are not subject to public procurement rules and local governments can be easily tempted to grant less competitive market conditions to local utilities in order to attract private investors. ${ }^{35}$ These developments are not fully monitored at present.

30. The most limiting aspect of the present budget implementation system is the quasi-exclusive focus of treasury controls on the conformity of spending to legal and procedural rules. Appropriations are laid out in detail in budget documents, and the PFO and CMO focus on their actual disbursement in stated uses. There is no checking mechanism in the system scrutinising that expenditures cater efficiently to their objectives -- or that services are provided in the technically most effective ways. Spending agencies, either line ministries or central and local budgetary institutions, receive a rather free hand in determining their "technologies" and organisations as long as these conform to legislated appropriations. Most often these are inherited from past exercises and reflect older organisational and supply structures.

31. This "input focused" approach to budget controls, which takes the existing supply organisations and their efficiency as given, contrasts with a "task focused" approach, which would target the outcomes of public services in terms of service availability and user benefits, and would seek to attain the most efficient ways for their delivery. The reliance of actual practices on the first approach is epitomised by the fiscal management of municipalities, which offer the bulk of public services. In the early transition, and in the wake of efforts to develop local democracy, ${ }^{36}$ municipalities throughout the country were vested with a large range of responsibilities to provide services in sectors as diversified as education, health, social

34. World Bank (2000a).

35. Such initiatives are a way of responding to market needs but to find the proper balance between private investment incentives and user interests should be their permanent concern.

36. Through the Local Government Act of 1990. 
assistance, water treatment, waste management etc. The funding of services was assured through central government grants (See Box 5).

\section{Box 5. Central funding grants for local service provision}

Following transition, the older 20 "county governments" have lost their prerogatives and municipalities have inherited very wide public service responsibilities (Table 7). The Local Government Act of 1990 mandated the central government to contribute to funding the costs of provision of these services.

The most important transfer types are the so-called normative grants. They contribute to the performance of local services according to elaborate service cost and service need formulas. There are 20 broad categories within the normative grant system, including entitlements such as child protection, housing services, basic healthcare services, tourism, institutions for the homeless, etc. Each category is broken down into numerous sub-categories. For example, the size of a normative grant for primary education differs by the facilities and services available in school buildings, the proportion of ethnic minority members or handicapped persons in the population, etc. The formulas determining the grants are subject to annual discussions within the budget process. These normative grants account for 60 per cent of total government transfers to municipalities; some grants fund the full costs of provision of services, but generally they co-fund the costs for 60-70 per cent while the municipalities provide the remaining top-up. ${ }^{1}$ A characteristic of normative grants has been the possibility of their re-allocation, by local governments, to other than originally intended purposes, a practice conflicting with the objective of earmarking central government transfers for priority areas.

Specific grants are less extensive and are not automatically granted. They are allocated on a more ad hoc and discretionary basis and come in two categories. Specific grants allocated under normative rules are dedicated to service areas. They are provided for instance for water purification, additional primary school services, hospital equipment, waste water collection etc. Specific grants distributed on an individual basis are allocated to specific projects approved by line ministries. They have recently financed many local economic development projects (such as tourism infrastructures). They also include the so-called "grants for disadvantaged localities for reasons beyond their control" which are offered to low-income local governments which lack sufficient revenues for the performance of their daily tasks (Table 7).

1. The co-funding by municipalities was intended to add an incentive for cost-effective service supply by local governments. In practice, however, this incentive seems to have remained relatively weak.

32. The present local government system consists of a large number of very small municipalities. Their average size is 3000 and their median size 1000 residents. ${ }^{37}$ Even if Hungary is not unique with respect to the small size of municipalities, ${ }^{38}$ its specificity is that these are vested with a very large number of tasks in comparison to their size. Serious questions then arise on the capacity of local governments to carry out these tasks efficiently. Beyond the problem of general managerial capabilities, they cannot cultivate any actual competition between alternative service units ${ }^{39}$ and cannot practice any benchmarking

37. Half of municipalities have therefore a population of less than 1000 persons and 300 (10 per cent of all municipalities) a population of below 200. The large difference between average and median populations reflects the weight of the municipality of Budapest where 18 per cent of the country population lives.

38. For example in France and the Czech Republic the average population per municipality is lower than in Hungary. 
between the quality and costs of services by different providers. The Local Government Act incorporates a chapter allowing local governments to create joint service supply organisations, and a new Act on Municipal Associations and Inter-Municipal Co-operation was passed in 1997, but actual incentives are limited for such co-operation. ${ }^{40}$

Table 7. Service responsibilities of local governments

\begin{tabular}{|c|c|c|c|}
\hline & Nordic countries & Southern Europe ${ }^{1}$ & Hungary \\
\hline Kindergartens & $X$ & & $x^{2}$ \\
\hline Primary education & $x$ & & $\mathrm{X}^{2}$ \\
\hline Secondary education & $x$ & & $x$ \\
\hline Daily child care & $X$ & & $x^{2}$ \\
\hline Health & $x$ & & $x^{2}$ \\
\hline Social welfare & $x$ & & $x^{2}$ \\
\hline Public safety & $X$ & & $\mathrm{X}$ \\
\hline Public lighting & $x$ & $X$ & $X^{2}$ \\
\hline Roads & $X$ & $X$ & $x^{2}$ \\
\hline Water & $X$ & $X$ & $\mathrm{X}^{2}$ \\
\hline Sewerage & $X$ & $X$ & $x^{2}$ \\
\hline Garbage collection & $X$ & $X$ & $\mathrm{X}$ \\
\hline Fire protection & $X$ & & $x$ \\
\hline Parks and recreation & $X$ & & $X$ \\
\hline Cemeteries & $x$ & $X$ & $x^{2}$ \\
\hline Housing & $X$ & $X$ & $X$ \\
\hline Minority rights & & & $x^{2}$ \\
\hline
\end{tabular}

1. For municipalities below 5000 .

2. Indicates compulsory.

Source: World Bank, 2000.

33. The potential role of "counties" (the traditional intermediary layer between the central and local government) in public service provision may deserve a re-examination. The counties do not have local tax authority and do not receive a share of the personal income tax. As a result, they are almost wholly dependent on the central government for financing. On the other hand, their tasks partly depend on decisions made by local governments. If a municipality is not able to finance secondary and vocational educational institutions, or a health care institution, it may transfer, at its own discretion, its responsibility to the county. The county then receives the associated normative grants, but only following the opt-out by the local government. ${ }^{41}$ The lack of an effective intermediary level between the central government and municipal levels appears as a structural problem in service supply because it limits the room for consolidation, scale economies, competition and quality and cost benchmarking between alternative service units.

39. Competition for markets remains in principle possible in local service markets which are natural monopolies. Bids for time-limited public service concessions are the medium of such competition. However, their design necessitates advanced management capabilities by municipalities (which should write contracts which balance investors' protection against commercial risks with consumers' protection against price abuse).

40. There is one minor financial incentive for municipalities to create associations for joint service supply, amounting to an additional one per cent top-up to central government grants.

41. An additional level of regional policy was created recently: To ensure that the country's regional policy is compatible with EU requirements and order to get access to the structural funds, seven statistical regions were put in place in 1996 (according to the NUTS2 level), but without real administrative competencies. 


\section{Reporting, auditing and closing of the budget accounts}

34. Strict rules of reporting, auditing and closing of budget accounts are defined by the Public Finance Act, independently from imperfections concerning the coverage and implementation of the general government budget. Final accounts for the central government, social security funds and extra-budgetary funds are presented to the Parliament within eight months of the year-end. They are audited by the State Audit Office (SAO) which has two months to give its opinion about these reports. During the year, monthly reports covering the central, social security and extra-budgetary accounts (but not of local governments) are sent within one month of month-end by the Ministry of Finance to the State Audit Office, the Government Control Office (GCO) and Parliamentary Budget Committee.

35. The GCO, operating under Prime Minister's office, effects internal audits and controls within the government, and verifies the effective workings of the control and audit units of the central budget organisations. The SAO is an independent constitutional agency. Its chairman and two vice-chairmen are appointed by Parliament for 12 years, and decide themselves their auditing priorities and programme. The ex-post audits of the SAO can cover any area with an incidence on the state budget, including the accounts of the central government, social security funds, extra-budgetary funds, transfers to local governments as well as the economy of local governments. In case of the more than 3000 local governments the frequency of the SAO audits is varying, the audit of local governments with significant budgetary contacts takes place every second or third year while the smaller ones are audited less frequently. ${ }^{42}$ The SAO also conducts ex ante audits, by reporting to Parliament on the reasonableness of budget law projections and the feasibility of revenue forecasts. The SAO makes all its reports public ${ }^{43}$ and, when it detects irregularities and if the character of these irregularities is such, it will initiate the judicial declaration of responsibility in each case.

36. The SAO is a credible and well-functioning agency, its main strength being ex-post legal, regularity and expediency audits. To its credit, it also detected unrealistic budget forecasts such as the underestimation of health spending projections in the 2001-02 budget. Its contributions can be reinforced by an extension of the Agency's rights and resources to cover local government accounts and to carry out task-oriented (functional) audits. One contribution in the area of functional audits was its inquiry into the inefficiencies of public debt management, which subsequently led to the creation of a specialised agency. ${ }^{44}$

42. The State Audit Office is indeed entitled to audit the financial management of the almost 3200 local governments, from the aspects of legality, expediency and -- in theory -- effectiveness. Besides the various individual audits, the SAO also presents a general appraisal of the financial management of the local government system each year to Parliament. However, the SAO does not have the capacity to perform almost 3200 local government audits each year, especially to carry out performance and effectiveness analysis. To strengthen the financial control, independent external audits were added to the local Government Act in 1995. Counties, cities with county rights, the capital city, districts of Budapest, as well as any local government with expenses of more than HUF 100 million and outstanding loans or credit are required to commission an auditor. According to the law, the municipalities have to carry out internal financial control, but only few local governments have the technical knowledge or sources to conduct effective internal financial control. The availability of such audits should facilitate municipal borrowing on capital markets in the future, and this provides municipalities an additional incentive to comply. Recognising the weakness of their internal audit capacity, some local governments have set up associations to co-operate on this issue.

43. Except in specific cases involving state secrets.

44. A working group with representatives from the Agency, Ministry of Finance, Central Bank and other state organs is examining currently the means of further improving the quality of public debt accounting. More accruals-based monitoring of debt costs, principles concerning face versus market value accounting of public debt, and the conversion of foreign currency denominated liabilities in a floating exchange rate system are on the agenda. An equally important matter seeking clarification and where little progress has 
Since functional audits in big cost items such as education and health require several years to complete with SAO's "bottom up" approaches, the agency has not undertaken such inquiries in practice.

\section{The challenges of reallocating resources in a medium-term perspective: the case of infrastructures}

37. The characteristics of budget institutions described above make substantive reallocations of resources in the budget system tricky. The low-key status of strategic policy orientations, and the lack of medium-term frameworks in the mainstream budget process ${ }^{45}$ in order to provide strategic focus for stepby-step shifts in spending composition (in progressive and politically acceptable ways) seem to make change more difficult. This inertia of expenditure composition conflicts at times with the emerging needs of the economy and society and pushes policy makers to develop special purpose entities outside the normal, transparent budget process.

38. There are several areas where there will be more demand for public resources and services in the future. These include the institutional and physical requirements of EU accession; ${ }^{46}$ demands for more even service quality across regions; ${ }^{47}$ public health activities in the face of the unsatisfactory health status of the population $;^{48}$ the need to better integrate the Roma minority through more effective human capital formation and labour market policies; ${ }^{49}$ upgrading the Research and Development infrastructure of the country $;^{50}$ and international obligations, including defence. ${ }^{51}$

been made is the monitoring of the total liabilities of quasi-fiscal off-budget institutions (including the state holding corporation APV, the development bank MFB and the railways company MAV) whose financial and other liabilities are de facto covered by the general government. The insufficient representation of the expenditures of these institutions in the general budget is echoed in the incomplete monitoring of total public debt.

45. A medium-term budgetary framework is prepared in the context of the pre-accession economic programme submitted to the European Commission but it is not part of national policy-making.

46. The total cost of adjustment to EU environmental regulations has been estimated, by the government, at around HUF 1820 billion over 2000-15, HUF 470 billion of which being earmarked for the period 201015. This amounts to total annual costs of 0.8 per cent of GDP in the first decade 2000.

47. These differences seem to have increased in the recent period, resulting from the "municipalisation" of public services under uneven local tax bases.

48. Health outcomes are unsatisfactory at present and deteriorated in a number of dimensions. They put Hungary at the bottom of OECD rankings. See OECD Health Data Base, 2001.

49. According to several indicators the Roma minority, representing between 5-10 per cent of the population, is falling behind in various dimensions of social development. Notably school achievements and labour market performances are extremely worrying. Only 1.6 per cent of Roma graduate from high school, compared with 23.8 per cent for non-Roma, while 0.24 per cent graduate from university, compared with 9.45 per cent for non-Roma. The non-employment rate for Roma reportedly attains 70 per cent. See US Department of State (2002). See also World Bank (2000a).

50. The objective of the government is to make the public R\&D system, heir to a brilliant scientific tradition, more responsive to market needs, by increasing the private/public joint financing of research projects. The government aims to double the share of R\&D expenditures in GDP from 0.8 per cent to 1.6 per cent in the early 2000s. This implies a strengthening of the public research facilities, notably in capital equipment and staff quality.

51. When acceding to the North Atlantic Treaty Organisation in 1998, Hungary committed to increase the share of defence expenditures from 1.5 per cent to 1.8 per cent of GDP in the 2000s. 
39. Infrastructure development is one of these increasingly solicited spending areas. Many infrastructure developments have been transferred to the market by privatisation of network utilities including electricity, gas and telecommunications services, but investment needs remain in water utilities ${ }^{52}$ as well as in road, water, rail and air transportation. In certain domains the "division of labour" between market and public services remains in flux, due to privatisation difficulties (air and bus transportation) or social and political obstacles (rail and postal services). Even in those areas where the completion of privatisation is in sight, fixed infrastructures will likely remain public and may necessitate large investments. This is now true of the road network, the electricity grid, the air traffic control system, as well as regional airports, the railway tracks and waterways in the geographical areas where these transportation modes have a role to play.

40. The management of public infrastructures has been erratic during the transition, where overly ambitious projects and underinvestments, privatisation and protection of central and local public monopolies have alternated. ${ }^{53}$ The international benchmarks and state-of-the art regulatory arrangements have also been a moving target, and this may have slowed reforms. As a result, capital intensive public infrastructures have fallen behind, notably in road, rail and regional air transportation, compared to the streamlining and growth of private economic activities. These developments have generated a considerable gap between available and necessary infrastructures.

41. Public opinion has reacted strongly to this state of affairs, particularly as infrastructure shortcomings became patent (long and unpredictable transportation times between many cities and regions, on all modes) and as foreign investors expressed discouragement in this area and began discriminating between locations according to infrastructure availability. This led also to strong political reactions. The main policy response was the elaboration of the "Szechenyi Plan", centred on motorway development across the country, and local infrastructure and facility development endeavours by local governments (see Box 6).

42. These activities have not found an appropriate place in the general government budget procedures. The lack of budget resources (captured by traditional expenditure items), and of multi-year planning horizons capable of directing them to new infrastructures drove the new plans and projects to offbudget courses. The cost of the planned central and local infrastructure projects has been projected to reach up to 8-9 per cent of GDP in the medium term, upon EU accession. ${ }^{54}$ If these additional expenditures were funded on an annual basis from the general budget, without offsetting cuts in other spending areas, they could easily move the share of primary expenditures in GDP back onto a growth path again.

52. Water utilities have not been transferred to the market sector. They are still operated by enterprises which are exclusively owned by the state or local governments.

53. A particularly illustrative case was the fate of the national motorway M1, the main highway between Budapest and Western Europe (see Box 5).

54. Communication to OECD by Hungarian authorities. 


\section{Box 6. Road development in the Szechenyi Plan ${ }^{1}$}

In the early period of transition, in a context characterised both by the need for freeway development and capital constraints, an international investment system in road concessions was devised. Consortia of local construction companies and private investors were granted construction and operating rights on individual routes, departing from established international practice where independent road operators first win concession tenders and then contract with road builders. The vertical integration model applied in Hungary led to soaring construction and material costs, and the freeway tolls rose to levels that most local motorists could not afford. The greater part of the traffic was forced back to old roads, with severe congestion -and pollution- problems, and the largest concession companies went bankrupt, though some of them were saved by budgetary bailouts. The general government also had to fund the precipitated construction of bypasses in the old road network to keep traffic flowing. The medium term development of the road network was not on a sustainable path.

When EU projects aiming at a European-wide road network took shape in the mid-1990s, the socalled "Helsinki channels of communication" targeted $1230 \mathrm{kms}$ of motorways in Hungary, with European and regional relevance. Only half of the nominated channels were of adequate "freeway" status (expressway or motorway). Hungary then re-designed its long-term domestic road development programme in reference to the European vision, with the objective of gradually raising its expressway intensity from $10 \mathrm{kms}$ for one thousand square kilometres to the European $40 \mathrm{kms}$, in a 30 years perspective. A 30-year road development programme has been finalised; this aims at a total of $3700 \mathrm{kms}$ of national freeways being in service in 2030 (among them $2000 \mathrm{kms}$ of expressways), effectively connecting Hungary to all neighbouring countries.

As a first step in its implementation, a ten-year construction programme of $702 \mathrm{kms}$ of new freeways by 2010 was finalised in 1999. At the turn of 2000, in response to both market pressures, notably by FDI investors who concentrated their investments in Budapest, its suburbs, and northern Transdanubia because of road network availability, as well as to more policy-driven motivations to stimulate remote regional economies and the construction sector, the government decided to accelerate the road development programme. Its planned duration was reduced from ten to seven years and a special momentum was given in 2001-02, in the framework of the Szechenyi Plan centred on additional public and private investments. ${ }^{2}$ Three major projects were phased in: the development of the M3 expressway between Fuzesabony and Polgar $(65 \mathrm{kms})$, the reconstruction of the M7 expressway between Budapest and Zamardi $(94 \mathrm{kms})$, and the construction of a bridge over Duna at Szekszard (19 kms together with associated freeways).

The organisation and financing of this effort takes place outside the general budget. The National Expressway company (NEL) was created, with a majority participation of the Hungarian Development Bank (MFB). NEL will execute the motorways programme, including preparing for construction, contracting-out and supervising the works. It is not subject to public procurement rules and selects bidders by its own decisions and criteria. MFB provides the majority (around 80 per cent) of the required resources, by direct loans (financed by issuing its own bonds) and providing guarantees to commercial banks lending to NEL. The State Expressway Management Company (SEH) was also created, by merging three existing state-owned motorway companies; it will be in charge of operating and maintaining the network. NEL and SEH are expected to recuperate only the maintenance costs of roads through toll revenues, and only in a medium-term perspective, with the recovery of the fixed investment in the road network through commercial revenues not being anticipated. The NEL spent HUF 90 billion on road investments in 2001, and is expected to spend HUF 180 billion in 2002.

1. See Ministry of Economic Affairs (2001).

2. A review of the Szechenyi Plan and its forecasted macroeconomic impacts can be found in OECD (2000a). 
43. In the case of the Szechenyi Plan the Hungarian Development Bank (MFB) has been activated, with new borrowing facilities and public counterguarantees (see Box 6). At the local level municipal investments are also expected to increase, as the total costs of the targeted projects has been estimated at a yearly 4-6 per cent of GDP during 2001-03. These estimates reflect local government intentions however and their intended funding sources (government grants, capital markets or international institutions) are not separately identified. Among these local initiatives, projects to be funded by off-budget utility companies may represent up to 2 per cent of GDP. ${ }^{55}$

44. These new developments raise serious concerns about the full public transparency, parliamentary accountability, cost-benefit fundamentals, managerial efficiency and future budget liabilities of the infrastructure projects. The "road construction" nexus including MFB, NEL and SEH (see Box 6) raises the greatest concern. MFB is a specialised credit institution coming under the Law on Credit Institutions, and hence under the surveillance of the Financial Supervisory Authority, but its special law gives it certain exemptions from standard prudential rules. Also, the "business confidentiality" of its operations, with the resulting restrictions and lags in government and public information on its activities, ${ }^{56}$ and the lack of control of Parliament over the activity of the bank causes discomfort. The large public works involved in road construction are also not subject to competitive Public Procurement Law, compounding the public concerns about the implications of departures from hard-won budget transparency and control rules. ${ }^{57}$

45. On the other hand, frustrations with the rigidity of budget procedures as well as with the poor state of the existing road network may be behind some of the current support, among the public and market players, ${ }^{58}$ to the activism of the Szechenyi Plan -- even if it uses unorthodox public finance procedures. Recognising such a trade-off would amount however to responding to one imperfection (lack of strategic focus and flexibility in budget procedures) by creating another more serious distortion (circumventing the transparency of public spending and undermining recent budget accountability efforts). There is a way out of this dilemma; the budget could be vested with a strategic multi-year framework with all public investments being integrated in the general government accounts, including and to begin with, the road investments of the Szechenyi Plan. Multi-year infrastructural budget appropriations could then be based on transparent cost-benefit analyses debated in public and approved by Parliament and could be "protected" from other budget contingencies, with large size public works being subjected to competitive procurement rules. In a more medium-term perspective however, and more fundamentally, as the total budget costs of all implied infrastructure investments might be excessively demanding for the Hungarian budget, soundly designed avenues for effective private sector participation in long-term infrastructure planning and investment should be explored. ${ }^{59}$

55. See World Bank (1999), IMF (2000).

56. The exercise of the shareholder's information and corporate governance rights in MFB is, according to its special law (paragraph 13), the prerogative of the "Minister designated by the Government". This task was re-allocated several times in the past among various ministries and is currently exercised by the minister leading the Prime Minister's Office (MEH). The other ministries get information with a lag: "The exerciser of the shareholder rights" gives account to the cabinet on a year's activities until 30 June of the following year. This regulation implies that the government has no control over the operation of the bank.

57. See Financial Times (2001).

58. 57 per cent of 500 business enterprises surveyed in May 2001 estimated that the Szechenyi Plan was contributing to long-term economic growth and dynamism.

59. See for example the discussion of the Public-Private Partnership method to infrastructure development in OECD (2002b). 


\section{Service supply structures can be considerably improved: the case of education}

46. Spending on education, of around 5 per cent of GDP, corresponds to the average OECD pattern. As the number of students fall and GDP grows at a fast average pace, the real value of education spending has increased in recent years. Even if the level of expenditures per student remains, not surprisingly, below wealthier OECD countries, the high share of public funding in total education spending is similar to the funding structure of education in many wealthier countries (Figure 6). This results from a law mandating free public education for all students until age 18 (and above in defined cases of vocational and higher education) and determining the minimum level of state support, which, in terms of the annual amount, cannot be lower than 90 per cent of total educational spending two years earlier. As teachers' wages are low by international standards, current funding ensures the commitment of large human resources to public education. The performance of Hungarian students in international tests used to be strikingly good ${ }^{60}$ and the attractiveness of Hungary for foreign direct investors is obviously due to the availability of highly skilled labour at competitive costs. International firms are prepared to provide additional on-the-job training to a basically well-educated workforce.

47. Nevertheless, there are emerging concerns about the quality and effectiveness of public education in Hungary. The most recent vintage of educational tests, which employ new student performance measurement methodologies, do not confirm the usual above-average performances of Hungarian students. In the new 2001 PISA $^{61}$ tests, which focus on applied skills, Hungarian students as a group found themselves for the first time among the "students performing significantly below the OECD average" in reading comprehension. Comprehensive tests of this character had not been conducted on a wide scale in Hungary before. Interpretations differ on the origin of this apparent deterioration of measured student performance. Policy makers and educators tends to recognise that student performance may not have kept pace with international progress and admit that success cannot come without reforming the educational methods, in order to equip students with modern problem-solving skills. ${ }^{62}$ Earlier national tests had indeed indicated that the deterioration in student performance has not been sudden. The National Assessment of Student Achievement had shown a decline of 12 per cent in $8^{\text {th }}$ grade reading performance and a 3 per cent fall in mathematics performance between 1991 and 1995, together with a growing regional disparity and a disparity between school types in results. These inequalities may explain the exceptional diversity of performances by Hungarian students in international tests ${ }^{63}$ likely reflecting the differentiation of their educational backgrounds across urban and rural areas, regions and individual education institutions.

48. Radical decentralisation of the education system during transition has shaped present supply structures. Local governments have been vested with not only the responsibility of owning and managing primary and secondary schools, ${ }^{64}$ but also of deciding the content of education, i.e. pedagogic programmes, within broadly defined national curricula. 1800 municipalities took over primary schools and 230 municipalities also secondary schools. The costs of primary and secondary schools were financed by central government grants, as in all other public services (see Box 5). After 1993, no centrally-defined

60. $\quad$ OECD (2001b) details test results in various disciplines in 1995 and 1999.

61. Programme for International Student Assessment. See OECD (2002 a).

62. A consultation with the Ministry of Education experts revealed that the authorities are well aware of the issue at hand.

63. Hungarian students are the group where the standard deviation of performance results increased the most (by 6 percentage points) between 1995-1999. See OECD (2001b).

64. When local municipalities are too small to host a secondary school, counties own and manage secondary schools. 
Figure 6. Education spending per student is in line with national wealth but uses more public resources than elsewhere

A. Annual expenditure per student, 1998 (1)
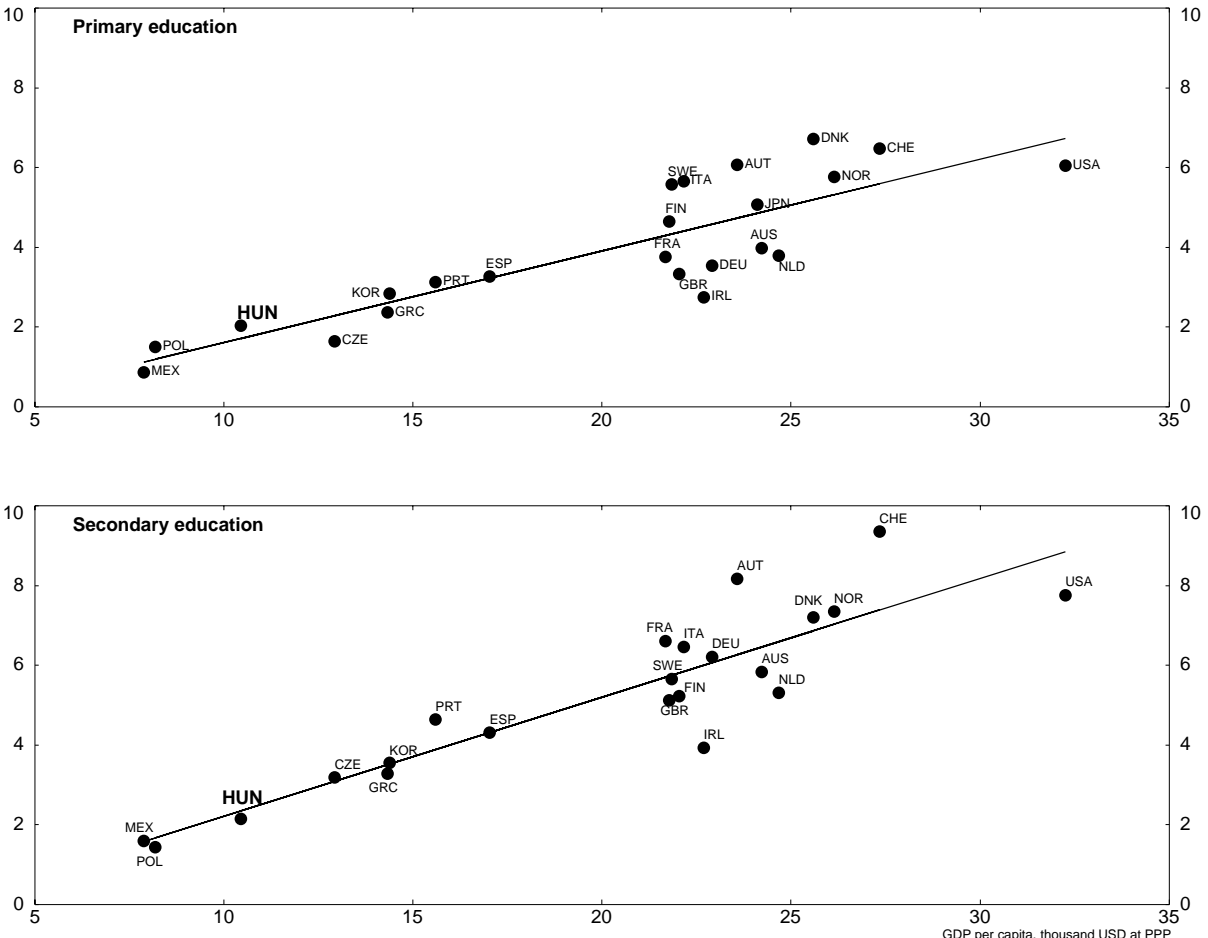

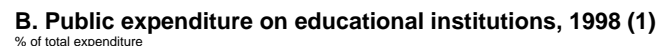

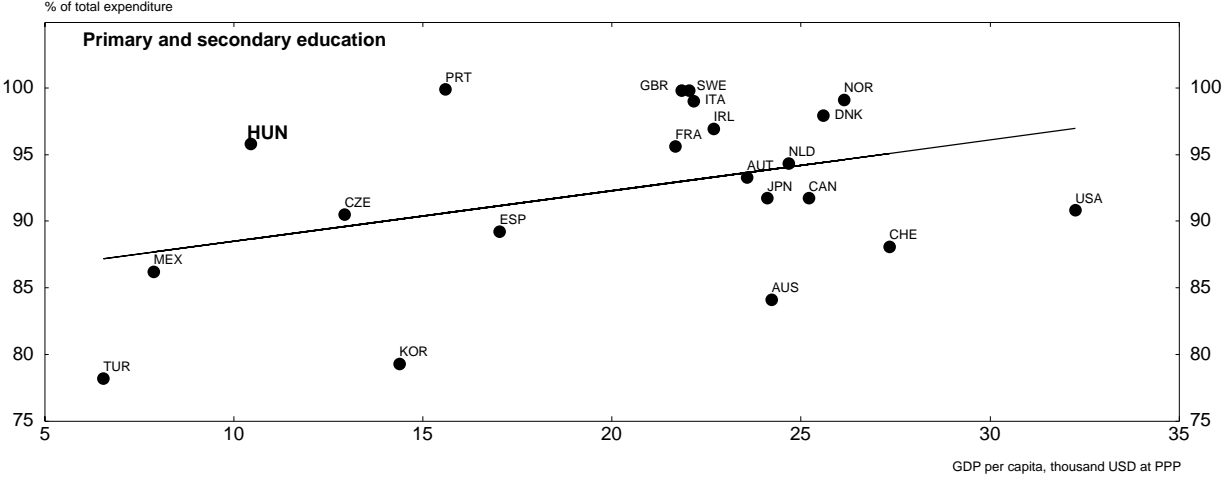

1. Public and private institutions.
Source: OECD (2001) Education at a Glance.

hunn2002/graphsledn expinp 10-Apr-02 (15:22:04) 
teaching methodology was mandated as a general rule. A wave of innovation resulted which was, however, severely curtailed by the significant (around 36 per cent) fall in real wages of teachers between 1990 and 1998. As a consequence, many competent teachers left the profession. The situation was similar in nonprofit schools run by foundations, and in the so-called "denominational" institutions, which grew in importance over the same period. ${ }^{65}$ The net outcome entailed many successful educational projects throughout the country, but also a large number of failures in establishing and implementing effective education. A 1998 survey revealed that one-third of primary and secondary schools were not able to prepare and operate their own curriculum but had to use curricula from outside sources. New framework curricula from the Ministry of Education (see below) aim at remedying this shortcoming. ${ }^{66}$

49. In the late 1990s, the Ministry of Education reacted to these outcomes of extreme fragmentation, which had been qualified by an OECD experts group as "one of the most decentralised education systems in the world, if not the most". ${ }^{67}$ The Ministry introduced a new policy of educational quality improvement, based on four pillars: modernising and enhancing educational content by the framework curricula; developing a national system of quality assessment and development; increasing central funding; and introducing a modern in-service training system for teachers. The main changes have been the publication of a new Framework Curriculum in 2000, more specific and mandatory than the previous Core Curriculum; the re-specification of the national diploma to be granted at the end of secondary school (GCSE) according to reinforced and homogenised examinations, to be effective in 2005; an education quality improvement programme, Comenius 2000, whereby schools are encouraged to implement a quality development system known from the industry, ${ }^{68}$ in connection with the launching of a comprehensive evaluation scheme, as well as a career model for teachers.

50. The basic economics of the education system remains as follows. Schools, especially those in smaller settlements, are in a position of local monopoly -- even if, legally, new schools can be created. In other areas, under the influence of demographic decline and the possibility of free choice between schools, education institutions compete for students. Educational institutions are funded on a per student-basis, within an output-oriented normative grant system that provides school operators (local governments, churches and foundations) the authority to decide the best utilisation of education grants, permitting them to reduce costs. ${ }^{69}$ However, an unintended outcome of this system has been the occasional re-allocation of education grants to other local government needs, making the operators of local schools decide on the amount of resources available for education. Beyond this implementation difficulty, and despite constraints in the adjustment of staff levels, operators of educational institutions have authority over staff level determination and organisational rationalisation (Table 8).

65. Foundations of civil, religious and ethnic groups created most of these new institutions. These receive the same central grants as municipal schools, which they then top up with their own resources. In 2001, they represented 6.5 per cent of schools and 5.2 per cent of students at primary ( 8 grade) level, and 17.4 per cent of schools and 10.1 per cent of students at the secondary level.

66. See OECD (2001e).

67. OECD $(2001 e)$.

68. Additional grants are made available to education institutions participating in these efforts. At the same time, those primary and secondary schools willing to stick to their original curricula and education programmes may continue to do so if they obtain proper quality control and certification by national authorities.

69. In principle, average school costs which are taken into consideration in establishing the normative grant levels can be calculated on the basis of educational best practices. The application of this principle requires a refined understanding of school costs in different geographical and social environments (and when dealing with different types of student groups). 
ECO/WKP(2002)22

\section{Table 8. Teaching and non-teaching staff in the education sector}

As a percentage of the total labour force

\begin{tabular}{|c|c|c|c|c|c|c|c|}
\hline \multirow[b]{2}{*}{ Selected countries } & \multicolumn{4}{|c|}{ Teaching staff } & \multirow[b]{2}{*}{$\begin{array}{l}\text { Administrative } \\
\text { personnel }\end{array}$} & \multirow[b]{2}{*}{$\begin{array}{c}\text { Maintenance } \\
\text { and } \\
\text { operations } \\
\text { personnel }\end{array}$} & \multirow{2}{*}{$\begin{array}{l}\text { Total } \\
\text { teaching } \\
\text { and non- } \\
\text { teaching } \\
\text { staff }^{1}\end{array}$} \\
\hline & $\begin{array}{l}\text { Pre-primary } \\
\text { education }\end{array}$ & $\begin{array}{l}\text { Primary } \\
\text { and } \\
\text { secondary } \\
\text { education }\end{array}$ & $\begin{array}{l}\text { Tertiary } \\
\text { education }\end{array}$ & $\begin{array}{l}\text { All levels of } \\
\text { education }\end{array}$ & & & \\
\hline Hungary & 0.8 & 3.6 & 0.5 & 4.9 & 0.8 & 1.4 & 7.1 \\
\hline Czech Republic & 0.4 & 2.1 & 0.4 & 2.9 & 0.9 & 0.8 & 5.4 \\
\hline France & 0.5 & 2.7 & 0.5 & 3.7 & 0.3 & 0.6 & 6.0 \\
\hline Italy & 0.5 & 2.9 & 0.3 & 3.7 & 0.5 & 0.5 & 5.0 \\
\hline Japan & 0.2 & 1.5 & 0.7 & 2.4 & 0.3 & 0.2 & 3.2 \\
\hline United States & 0.4 & 2.2 & 0.7 & 3.3 & 0.7 & 1.0 & 6.4 \\
\hline OECD mean & 0.3 & 2.6 & 0.6 & 3.5 & 0.5 & 0.6 & 5.4 \\
\hline
\end{tabular}

1. Includes teacher aides and teaching research assistants; professional support for students; management -- within or beside the sub-categories of this table.

Source: OECD, $2001 b$ (Table D2.4, D2.5).

51. Local governments have carried out some reorganisation measures, but these have nearly always entailed serious local conflicts. The planning of reorganisation was supported by the amendment to the Act on Public Education, which mandated the preparation of county development plans in 1996 and of institutional-operational plans in 1998. This regulation was aimed at ensuring better planning and better provision on the part of municipal governments. County development plans can encourage establishing associations of municipal governments; this arrangement could contribute to the rationalised operation of the fragmented administrative system. After 1998, an incentive programme was launched for small settlements where the number of students was too low for the effective employment of specialised teachers: small settlements received support in exchange for undertaking certain tasks contributing to quality education and more effective operation. Generally, the number of non-teaching personnel also appears to be exceptionally high.

52. Regarding demand, recipients of services (students, parents, business organisations, etc.) are increasingly characterised by the will to be better informed; and, as a result of the competitive situation and the quality development programme, a portion of the schools are responsive to these efforts. At the same time, in settlements where parents have limited selection possibilities, these processes are slower. School catchment areas have been widened recently, permitting well-informed and motivated parents in large urban areas to select the school for their children according to reputation and quality. In addition to the central funding they receive proportionally to the number of students that they are able to attract, schools located in wealthier municipalities and those run by well-off foundations or churches can also get additional resources directly from local governments or through fees for extra-curricular services (additional courses, day care, etc.) from students' families with the ability to pay. The largest problem remains in the regions and areas where these mechanisms of market emulation, reward and sanction do not operate, and where school principals and teachers have eroded incentives. ${ }^{70}$ With recipients of services having little information, no choice and no ability to pay, a strong central "principal" (the Ministry of Education) as a purchaser of services, rewarding and funding the schools according to performance and output norms, may help enhance performance and quality. The Ministry of Education's recent efforts go in this direction.

70. National data bases of education programmes, practices and curricula have been developed and constitute useful public reference tools. Their effective use depends on school principals' and teachers' incentives and abilities. 
53. The rigidity of teacher employment is not stronger in Hungary than in other OECD countries, but raises more difficult challenges as the student population shrinks. ${ }^{71}$ In consequence, teacher-to-student ratios have become particularly high in international comparison. ${ }^{72}$ As an unintended result, and although Hungary spends the same share of its GDP per capita per primary and secondary student as other OECD countries ${ }^{73}$ teachers' wages hardly reach the per capita GDP. ${ }^{74}$ Due to measures aimed at wage increases over the last few years, however, teachers' wages in 2002 will be above (112 per cent) the national average wage. Moreover, a teaching diploma in the rapidly developing Hungarian economy proves marketable, allowing many teachers to change their career. Present efforts to raise the real wages of teachers, as well as the teacher's career model in preparation aim at facing this challenge. ${ }^{75}$

54. In a longer-term perspective, the resources that the country will decide to make available for education services will be a matter of national preference. There are large spending claims in this area (for instance, Hungarian schools are under-equipped in new technologies ${ }^{76}$ ) and new targeted skills for students require new approaches and new competencies from teachers. ${ }^{77}$ Meanwhile part of the most dynamic teachers (and would-be teachers) have alternative opportunities in the labour market, so that the opportunity costs of employment in education are growing. The education problems facing the Roma population also claim additional resources and measures. ${ }^{78}$ In the future, the national education priorities and the resources available for them should be made more explicit through long-term government-level strategies, with a multi-year funding framework.

71. The 15-19 age cohort of secondary school students comprised 856000 members in 1995 and 654000 in 2000 .

72. In primary education, the average ratio of student per teacher was 12.1 in $1991,10.8$ in 1996 and 11.2 in 2000. In secondary education the averages were 14.4 in 1991, 13 in 1996 and 12.4 in 2000.

73. The proportion is above the OECD average in higher education.

74. With average annual wages of $\$ 10000$ at PPP rates for tenured (15 years' experience) teachers in secondary education in 1999, Hungary pays, together with the Czech Republic and Turkey, the lowest teacher salaries in the OECD area. It is one of four Member countries where teachers' average wages are lower than per capita GDP.

75. The real wages of primary and secondary school teachers had fallen to 64 per cent of their 1990 level by 1998. A catch-up policy, started in 1999, granted them a 7.6 per cent real increase in that year, 3.3 per cent in 2000, 6.7 per cent in 2001 and the government pre-announced a 15 per cent real increase for 2002 . The stated objective is to offset most of the earlier accumulated losses by the end of 2002.

76. Hungary had one of the lowest computer equipment rate in its schools in 1999, with 48 per cent of schools equipped against an OECD average above 70 per cent (OECD, 2000b). World Information Technology and Services Alliance (2000) confirms this comparative IT lag of Hungary in education, see the section on worldwide installed base of PCs in education markets.

77. Innovative "training-in-service" programmes have been put in place by the Ministry of Education. Grants fund not the existing teacher-training organisations but directly the purchasers of services (schools and teachers) which can work with the institutions of their preference -including newly entering for-profit (commercial) service providers. The Ministry of Education certifies the skills of these private organisations and accredits them for participation in the programme.

78. Until recently, it was common that students with weaker backgrounds would drift to educational deadends, including into institutions for children with mental disabilities. In 1999, an amendment in the Public Education Act tried to contain such drifts by making more resources available for dealing with this problem. Today the fact of disability can only be declared by "Professional and Rehabilitational Committees" on the basis of complex examinations. 3.6 per cent of basic education students are at present enrolled in schools for disabled students, 82 per cent of them having slight mental disability. A reexamination is obligatory in order to direct a student back into normal school when possible. 


\section{Policy recommendations and summary}

55. Hungary has achieved much progress in the management of its public finances through the first decade of transition but there remains significant room for further advances, both in order to diminish the total tax burden and to improve spending outcomes by making it more responsive to the changing needs of the economy and society. Two guiding principles in strengthening the management of public expenditures should be: i) more legislative control and commitment, more clarity and longer time horizons in decisions on spending priorities; and ii) an improvement of public service supply structures with local taxpayers and central funding agencies playing a more informed and active role in controlling the efficiency of services and the relevance of their supply modes. The following box summarises the recommendations arising from this analysis of the public expenditure system (Box 7).

\section{Box 7. Strengthening the management of public spending}

\section{The share of public spending and taxation in GDP}

- Reduce the share of total primary spending in GDP to 41.5 per cent by 2004 (as announced in the PEP of April 2001).

- Fix a subdued real expenditure growth target, and build a social and political consensus on it (the rate could lag the potential growth rate by 1 per cent).

- Make a conservative GDP growth assumption for the budget baseline, and dedicate the majority of revenue and inflation windfalls (say 75 per cent) to deficit reduction and a smaller portion to discretionary expenditure and tax reductions.

- Explore avenues for private sector participation in long-term infrastructure planning and investment. Devise more economically efficient methods than in the past, by taking into account the best-practice international experience. This can be applied notably to the development of new roads and regional airports.

- Analyse the efficiency of the existing public service supply. In areas where excessive fragmentation between municipalities curbs competition and efficiency, consolidate supply structures via voluntary associations or by furthering the role of an intermediate level of government.

- In areas where local monopolies are natural, reduce their costs and increase the quality of their services by giving local taxpayers and central funding agencies more direct control over their activities (by making them more powerful "principals" for their services). In education services, this may be done by utilising performance benchmarks in re-confirming the mandates of school principals -- who should preserve some discretion over the effective utilisation of "per student" grants.

The coverage and transparency of budget procedures

- Consolidate all quasi-fiscal activities in the budget (the policy-driven activities of APV, MFB and the National Motorway Company). In this context, create public service accounts for MAV and integrate them into the general government budget.

- Publish the expected realisation (call) rates on new MFB and SME guarantees and provision the budget accordingly.

- Fix a target date for producing accrual-based ESA 95 budget accounts on a regular (quarterly or monthly) basis and provide the Central Statistical Office with the necessary resources.

The preparation of the budget

- A government policy statement should be elaborated at the beginning of each legislature as a strategic policy framework.

- A medium-term budgetary framework based on medium-term expenditure targets should serve as a reference for annual budgets. 
- A task-oriented budget (organised into functional chapters) should accompany the institutionally-oriented budget.

- A yearly policy statement should outline the corresponding priorities of the budget

- An integrated national infrastructure investment programme should be prepared. Interdependencies between infrastructures (notably between transportation modes) and between national and regional networks should be clarified. Cost-benefit analyses should be a standard input to this programme.

- Involve local governments in the multi-year strategic budget process recommended above. Have local governments produce their own medium-term fiscal programmes and frameworks.

- Clarify macroeconomic assumptions of the multi-year and annual budget frameworks. Open alternative scenarios to public discussion and make the fiscal risks transparent.

- Estimate structural (cyclically-neutral) budget expenditure, revenue and deficit targets.

Budget implementation and control

- Building on the development of accrual-based ESA 95 accounts, develop accrual-based budget monitoring in addition to cash monitoring.

- Apply public procurement rules to quasi-fiscal organisations (Motorways companies, MAV, MFB, APV).

- Extend monthly budget monitoring to local governments.

- Set performance benchmarks for service supply efficiency. Trigger management and organisation changes when targets are not met.

- Replace (gradually, also using pilot projects) input-oriented financing with output-oriented financing.

- Consolidate inefficient local service supply units by administrative means.

- Monitor local governments' off-budget utility companies' activities in the framework of local government budgets.

- Revise the exemptions to local borrowing caps. Replace sectoral exemptions by exemptions based on project characteristics (for example, degree of actual risk sharing by private investors, or availability of audited costbenefit analyses).

- Extend public procurement rules to all local investment spending (including by off-budget utility companies) above a critical threshold level.

Auditing and closing of accounts

- Develop further the functional audit capabilities of the State Audit Office (SAO) and require pre-defined output indicators to be provided by public service agencies.

- Encourage additional functional audits in the main functional areas of the budget (such as higher education, primary and secondary education, primary, secondary and tertiary health services, social assistance schemes). Make research grants available for the study of the functional performance of services by independent research bodies. Involve private consultancy companies in such functional audits.

- Develop the regional activities and agencies of the SAO for local government audits. 


\section{BIBLIOGRAPHY}

Atkinson, P. and P. Van den Noord (2001),

"Managing Public Expenditure: Some Emerging Policy Issues and a Framework for Analysis",

OECD Economic Department Working Papers, No. 285, February.

Bleaney, M. N. Gemmell and R. Kneller (2001),

"Testing the endogenous growth model: public expenditure, taxation and growth over the long run."

Canadian Journal of Economics. Vol. 34, No.1, 36-57.

Chalk, N. and R. Hemming (2000),

"Assessing Fiscal Sustainability in Theory and Practice", IMF Working Papers, No. 00/81.

Doyle, P. et al (2001),

"Real Convergence to EU Income Levels: Central Europe from 1990 to the Long Term." IMF

Working Papers. No. 01/146, September.

EC (2001),

2001 Regular Report on Hungary's Progress Towards Accession, Brussels, November.

EC (2002),

"Evaluation of the 2001 pre-accession economic programmes of candidate countries", Enlargement Papers, No. 7, Directorate-General for Economic and Fiscal Affairs.

Eddy, K. (2001a),

"Controversy surrounds the question of how to fund improvements to the country's overcrowded motorways and overhaul the loss-making railways", Financial Times, 20 November 2001.

Éltetö, A. (2001a),

"The competitiveness of Hungarian companies", The Hungarian Academy of Sciences Working Papers, No. 118, August.

Financial Times (2001),

Special Issue on Hungary, Article on the administration of road construction contracts, [5]

December 2001.

GKI (2001a),

Economic Outlook for Hungary 2001-2002. Budapest, November.

Government of Hungary (2001),

Pre-Accession Economic Programme of the Republic of Hungary, Budapest, April. 


\section{ECO/WKP(2002)22}

Government of Hungary and European Commission (2001),

Joint Assessment of the Employment Policy Priorities of Hungary, Budapest and Brussels, November.

Gupta, S. L.Leruth, L. de Mello and S. Chakravati (2001),

Transition Economies: How Appropriate Is the Size and Scope of Government?, IMF Working Papers, No. 01/55.

Havas, G. et al (2001),

"Cigány gyerekek az általános iskolákban", Papers of the Hungarian Institute for Educational Research, No. 231.

Hviding, K. (1999),

"Potential Output Growth in Hungary", in Hungary - Selected Issues, IMF, EU1, 3 February.

$\operatorname{IMF}(2001 a)$,

On the Road to EU, Washington.

$\operatorname{IMF}(2001 b)$,

Report on the Observance of Standards and Codes: Hungary, IMF, 18 April 2001.

Joumard, I. (2001),

"Tax systems in European Union countries", OECD Economics Department Working Papers, No.301.

Kaminski, B. and M. Riboud (2000),

"Foreign Investment and Restructuring: The Evidence from Hungary", World Bank Technical Papers, No. 453, March.

Kiss, G. and G. Szapary (2000),

"Fiscal Adjustment in the Transition Process: Hungary, 1990-1999", Post-Soviet Geography and Economics, Vol. 41, no.4.

Kollo, J. (2001a),

"The patterns of non-employment in Hungary's least developed regions", Budapest Working Papers on the Labour Market, no. 2001/1.

Kollo, J. (2001b),

Contribution to the minimum wage debate, Economic Review (Kozgazadasagi Szemle, in Hungarian), December 2001.

Kopanyi, M., S.Daher, D.Wetzel, M.Noel, A.Papp (2000),

"Hungary: Modernising the Subnational Government System", World Bank Discussion Papers, No.417

Kornai, J. (2001),

"Hardening of the budget constraint: The experience of the post-socialist countries", European

Economic Review, Vol 45, 1573-99.

Kun, J. (2001),

"Old-age pension systems in the Czech Republic, Hungary and Poland", Focus on Transition, No.2, The Austrian National Bank, Vienna. 
Lorant, K. (2002),

"A magyar 'csoda"”, Cégvezetés, February, pp. 90-99.

Lutz, M., E. Ruggiero, P. Bernd Spahn and E. Sunley (1997),

"Hungary", in T. Teer-Minassian ed., Fiscal Federalism in Theory and Practice, International Monetary Fund.

Ministry of Economic Affairs (2001),

Széchenyi Plan, Budapest, February.

Ministry of Education (2000a),

Higher Education in Hungary in the Year of the Millenium. Budapest.

Ministry of Education (2000b),

Science and Technology 2000: The Hungarian Government's Action Program, Budapest.

OECD (1995),

Social and Labour Market Policies in Hungary, Paris.

$\operatorname{OECD}(1999 a)$

Economic Survey of Hungary, Paris.

OECD (1999b),

Thematic Review of the Transition from Initial Education to Working Life: Hungary, Paris.

$\operatorname{OECD}(2000 a)$,

Economic Survey of Hungary, Paris.

OECD (2000b),

Reviews of Foreign Direct Investment: Hungary, Paris.

OECD (2001a),

Economic Survey of the Czech Republic, Paris.

$\operatorname{OECD}(2001 b)$,

Education at a Glance: OECD Indicators, Paris.

OECD (2001c),

Taxing Wages: 1999/2000, Paris.

OECD (2001d),

Businesses' Views on Red Tape: Administrative and Regulatory Burdens on Small and Mediumsized Enterprises, Paris.

OECD (2001e),

New School Management Approaches, Paris.

OECD (2001f),

Territorial Review of Hungary, Paris. 
OECD (2001g),

Fiscal Design Across Levels of Government: Hungary, Directorate For Financial, Fiscal and Enterprise Affairs, Paris.

OECD $(2001 h)$,

"OECD Best Budget Practices", PUMA.

OECD (2002a),

Knowledge and Skills for Life: First Result from PISA 2000, Paris.

OECD (2002b),

"Policies to enhance efficiency in publicly funded services: issues and experiences among OECD countries", ECO/CPE/WP1(2002)6, Paris.

Office for National and Ethnic Minorities (2000),

Measures taken by the state to promote the social integration of Roma living in Hungary, Budapest, Ministry of Foreign Affairs.

Orosz Eva and Andrew Burns (2001),

"Health Reform in Hungary", OECD Economics Department Working Papers.

Papanek, G. (2000),

"The relationship between science, industry and government, a country in transition", A paper presented to the $3^{\text {rd }}$ Triple Helix Conference at Rio de Janeiro.

Polackova, H. (1998),

"Government Contingent Liabilities: A Hidden Risk to Fiscal Stability", World Bank Policy

Research Working Paper.

Polackova, H., A. Papp and A. Schick (1999),

"Fiscal Risks and the Quality of Fiscal Adjustment in Hungary", World Bank Policy Research Working Papers, No.2176.

Redmond, G. and P. Kattuman (2001),

"Employment polarisation and inequality in the UK and Hungary", Cambridge Journal of Economics, Vol. 25, 467-480.

Rocha, R. and D. Vittas (2001),

"Pension Reform in Hungary: A Preliminary Assessment", World Bank Policy Research Working Papers, No. 2631, July.

Transparency International (2001),

Global Corruption Report, Berlin.

US State Department (2002),

2001 Country Reports on Human Rights Practices: Hungary, Washington, D.C., 4 March.

World Bank (1999),

Hungary: On the Road to the European Union, World Bank Country Study, November 1999.

World Bank (2000a),

Modernising the Subnational Government System in Hungary. 
ECO/WKP(2002)22

World Bank (2000b),

Social Development Report in Hungary.

World Information Technology and Services Alliance (2000),

Digital Planet 2000: The Global Information Economy, http://www.witsa.org/dplanet. 


\section{ANNEX I OECD ADJUSTMENTS TO THE GFS ACCOUNTS IN HUNGARY}

The OECD data on public expenditure in Hungary used in this Survey are derived from the official GFS data but with adjustments in several aspects in order to enhance international comparability, since SNA93 (or ESA95) accounts are not yet available. ${ }^{79}$

The most notable changes include the treatment of privatisation revenues, of "lending minus repayments" as financing items rather than above the line transactions (that affect the budget balance), and the inclusion of an estimation of infrastructure investments by off-budget companies. The social security contributions paid for its own employees by the government, which are usually consolidated within the general government according to the GFS accounts, are added back to both the government revenues and expenditures in accordance with SNA93 principles. In addition, the net balance of the APV (the Privatisation and State Holding Corporation), which is classified as a part of the general government sector according to the Eurostat, is added to the aggregate spending -- but not the consolidated revenue and expenditure due to a lack of data. The final adjustment that affects the balance and the overall spending level concerns the accrual adjustment of interest payments and value-added-taxes. For these figures, OECD relies on the figures estimated by the National Bank of Hungary.

To enhance the cross-country comparability of expenditure components, spending items are rearranged in the following way to reflect the nature of spending. Healthcare payments paid by the compulsory insurance regime, which are booked as income transfers in the GFS, are rearranged as government non-wage consumption. Similarly the indirect price subsidies to households, categorised as income transfers in the GFS accounts, are reclassified as a part of subsidies to enterprises -- they include the transportation subsidies for students and elderly, and subsidies on pharmaceutical products. The unallocated expenditures (and revenues) are assumed to constitute a part of capital transfers as the nature of the spending is not known. ${ }^{80}$

While those adjustments intend to bring the published GFS accounts closer to the SNA standard, data may not be fully in line with the ESA95 accounts which will be available in the near future (at present the ESA95 deficit and debt figures are available only for 1997-2000, and they are claimed to be preliminary and subject to change). For example, the coverage of general government in the GFS on which the OECD adjustments are based is narrower than that in the ESA95. Though the balance of the APV is included in that of general government, lack of further details on APV's revenues and expenditures limits the full reflection of its activities in the general government accounts. In a similar vein, the fiscal activities

79. A similar method of converting the official GFS data into the SNA-compatible format was also made for the Czech Republic whose public spending was reviewed by the last Economic Survey of the Czech Republic.

80. For example, the unallocated expenditure of HUF 120 billion for 2000 appears to be used to pay for a oneoff increase in wages and old-age pensions, housing rent programs and subsidies to the APV, while some of this expenditure remained on the Treasury account and was spent in 2001. 
of 120 non-profit organisations -- that are left outside of the GFS accounts but which are to be included as a part of general government by the ESA95 -- are ruled out in calculating general government expenditures (although, fortunately, the deficits of those institutions are usually covered by the transfers from the state budget and therefore are included in the budget balance already). Expenditures of the national motorway company are included in the OECD and ESA95 accounts but excluded from the GFS accounts. In addition, a lack of relevant information leads the OECD to add accrual adjustment of net interests payments to the spending side only. No imputation for the depreciation of government fixed capital has been made.

The OECD estimates are broadly in line with the ESA95 budget balance for those years where both are available, and historical trends are similar between the OECD estimates and those of the National Bank of Hungary. 


\section{ECONOMICS DEPARTMENT \\ WORKING PAPERS}

335. Automatic Stabilisers and Market Flexibility in EMU: Is There a Trade-Off?

(July 2002) Marco Buti, Carlos Martinez-Mongay, Khalid Sekkat and Paul van den Noord

334. The Economic Consequences of Terrorism

(July 2002) Patrick Lenain, Marcos Bonturi and Vincent Koen

333. Investment in human capital through post-compulsory education and training: Selected efficiency and equity aspects

(July 2002) Sveinbjörn Blöndal, Simon Field and Nathalie Girouard

332. Enhancing the Effectiveness of Public Spending in Switzerland

(June 2002) Isabelle Joumard and Claude Giorno

331. Competition and Efficiency in Publicly Funded Services

(June 2002) Jens Lundsgaard

330. Policy Pre-Commitment and Institutional Design: A Synthetic Indicator Applied to Currency Boards (May 2002) Marie-Thérèse Camilleri Gilson

329. The Role of Policy and Institutions for Productivity and Firm Dynamics: Evidence from Micro and Industry Data

(April 2002) Stefano Scarpetta, Philip Hemmings, Thierry Tressel and Jaejoon Woo

328. Improving the Efficiency and Sustainability of Public Expenditure in the Czech Republic (April 2002) Andrew Burns and Kwang-Yeol Yoo

327. Increases in Business Investment Rates in OECD Countries in the 1990s: How much can be explained by fundamentals?

(April 2002) Florian Pelgrin, Sebastian Schich and Alain de Serres

326. Sectoral Shifts in Europe and the United States: How They Affect Aggregate Labour Shares and the Properties of Wage Equations

(April 2002) Alain de Serres, Stefano Scarpetta and Catherine de la Maisonneuve

325. Coping with Population Ageing in the Netherlands

(March 2002) David Carey

324. Public Spending in Italy: Policies to Enhance its Effectiveness

(March 2002) Alexandra Bibbee and Alessandro Goglio

323. Overheating in Small Euro Area Economies : Should Fiscal Policy React?

(March 2002) Peter Hoeller, Claude Giorno and Christine de la Maisonneuve

322. Encouraging Environmentally Sustainable Growth in Austria

(February 2002) Jens Høj and Andreas Wörgötter

321. Health Care Reform in Japan

(February 2002) Yutaka Imai

320. Enhancing Expenditure Control with a Decentralised Public Sector in Denmark (February 2002) Steen Daugaard 
319. Options for Reforming the Finnish Tax System (February 2002) Isabelle Joumard and Wim Suyker

318. Product Market Regulation and Wage Premia in Europe and North America: An Empirical Investigation (January 2002) Sébastien Jean and Giuseppe Nicoletti

317. Competition, Innovation and Productivity Growth: A Review of Theory and Evidence (January 2002) Sanghoon Ahn

316. Labour Market Institutions, Product Market Regulation, and Innovation : Cross Country Evidence (January 2002) Andrea Bassanini and Ekkehard Ernst

315. Ongoing Changes in the Business Cycle - Evidence and Causes (January 2002) Thomas Dalsgaard, Jorgen Elmeskov and Cyn-Young Park

314. Comment encourager une croissance ecologiquement durable en France? (December 2001) Ann Vourc'h et Patrick Lenain

313. Increasing Efficiency and Reducing Complexity in the Tax System in the United States (December 2001) Richard Herd and Chiara Bronchi

312. Product and Labour Markets Interactions in OECD Countries (December 2001) Giuseppe Nicoletti, Andrea Bassanini, Ekkehard Ernst, Sébastien Jean, Paulo Santiago and Paul Swaim

311. Modelling Import Responsiveness for OECD Manufactures Trade (October 2001) Mara Meacci and David Turner

310. Trade Linkages and the Trade Matrices in the OECD Interlink Model (October 2001) Laurence Le Fouler, Wim Suyker and Dave Turner

309. Encouraging Environmentally Sustainable Growth in Australia (October 2001) Ann Vourc'h and Robert Price

308. Financial Market Liberalisation, Wealth and Consumption (September 2001) Laurence Boone, Nathalie Girouard and Isabelle Wanner

307. The Economic Integration of Germany's New Länder (September 2001) Eckhard Wurzel

306. Standard Shocks in the OECD Interlink Model (September 2001) Thomas Dalsgaard, Christophe André and Pete Richardson

305. Fiscal Implications of Ageing: Projections of Age-related Spending (September 2001) Thai Thanh Dang, Pablo Antolin and Howard Oxley

304. The Width of the Intra-European Economic Borders (August 2001) Alain de Serres, Peter Hoeller and Christine de la Maisonneuve

303. Surveillance of Tax Policies: A Synthesis of Findings in Economic Surveys (July 2001) Paul van den Noord and Christopher Heady

302. Reforming the Tax System in Portugal (July 2001) Chiara Bronchi, José C. Gomes-Santos 